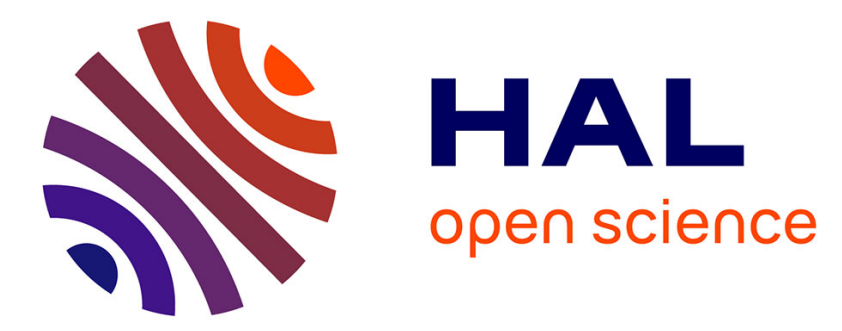

\title{
Supported metallic nanoparticles prepared by an organometallic route to boost the electrocatalytic conversion of $\mathrm{CO} 2$
}

\author{
B.C. Marepally, C. Ampelli, C. Genovese, R. Sayah, L. Veyre, C. Dalverny, \\ Chloé Thieuleux, E.A. A Quadrelli, S. Perathoner, G. Centi
}

\section{To cite this version:}

B.C. Marepally, C. Ampelli, C. Genovese, R. Sayah, L. Veyre, et al.. Supported metallic nanoparticles prepared by an organometallic route to boost the electrocatalytic conversion of CO2. Journal of CO2 Utilization, 2021, 50, pp.101613. 10.1016/j.jcou.2021.101613 . hal-03357231

\section{HAL Id: hal-03357231 \\ https://hal.science/hal-03357231}

Submitted on 30 Sep 2021

HAL is a multi-disciplinary open access archive for the deposit and dissemination of scientific research documents, whether they are published or not. The documents may come from teaching and research institutions in France or abroad, or from public or private research centers.
L'archive ouverte pluridisciplinaire HAL, est destinée au dépôt et à la diffusion de documents scientifiques de niveau recherche, publiés ou non, émanant des établissements d'enseignement et de recherche français ou étrangers, des laboratoires publics ou privés. 


\title{
Supported metallic nanoparticles prepared by an organometallic route to boost the electrocatalytic conversion of $\mathrm{CO}_{2}$
}

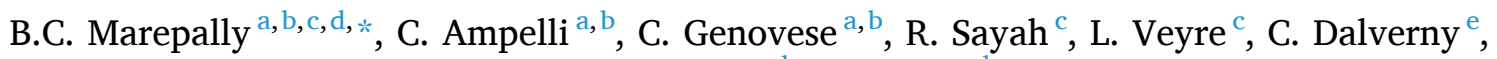 \\ C. Thieuleux ${ }^{c}$, E.A. Quadrelli ${ }^{c}$, S. Perathoner ${ }^{a, b}$, G. Centi ${ }^{\text {a,b, }{ }^{*}}$

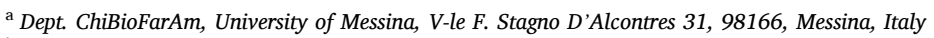 \\ ${ }^{\mathrm{b}}$ ERIC aisbl, Bruxelles, Belgium \\ ${ }^{\mathrm{c}}$ Université de Lyon, Institut de Chimie de Lyon, UMR 5265 - CNRS -CPE Lyon - Université Lyon 1, CPE Lyon, Laboratoire de Chimie, Catalyse, Polymères et Procédés \\ (C2P2), Equipe Chimie Organométallique de Surface, 43, Bd du 11 Novembre 1918, F-69616, Villeurbanne, France \\ ${ }^{\mathrm{d}}$ Dep. of Electronics and Communication Engineering, Koneru Lakshmaiah Education Foundation, Hyderabad, TS, 500075, India \\ ${ }^{\mathrm{e}}$ Université Lyon 1, Centre technologique des microstructures, 5 rue Raphael Dubois, 69622, Villeurbanne, France
}

\section{A R T I C L E I N F O}

\section{Keywords:}

$\mathrm{CO}_{2}$ electroreduction

Metal nanoparticles

Organometallic preparation

Ru nanoparticles

Carbon dioxide

\begin{abstract}
A B S T R A C T
Electrocatalysts based on metal nanoparticles (metal $=\mathrm{Ru}, \mathrm{Fe}$ and $\mathrm{Pt}$ ), prepared by an organometallic (OM) route, and supported on carbon nanotubes (CNTs), have been studied in the electro-catalytic reduction of $\mathrm{CO}_{2}$ in comparison with those prepared using inorganic salts to deposit the metal nanoparticles (NPs) over CNTs (INORG route). The OM route allows to obtain electrocatalysts with superior performances in terms of productivity and especially turnover frequency, with an enhanced formation of C1 products (methanol and formic acid) with respect to $\mathrm{C} 2+$ products (acetic acid, acetone, isopropanol and ethanol). Particularly for Ru samples, there is an increase up to nearly two order of magnitude in the cumulative TOF with respect to a sample with an equivalent metal loading and mean particle size but prepared by the INORG route. Carbon selectivity to methanol reaches the interesting value of $65 \%$. The analysis of this intrinsic boosting of both activity and selectivity in the electrocatalytic reduction of $\mathrm{CO}_{2}$ suggests a role in this enhanced performance of small oxide patches on the metal nanoparticles formed as residues of the process of removal of the ligands present in the OM route.
\end{abstract}

\section{Introduction}

The electrocatalytic reduction of $\mathrm{CO}_{2}$ is a topic of large and increasing scientific interest, as indicated by many recent reviews [1-14]. Electrocatalysis is a key crucial technology to develop viable processes to yield chemicals using renewable energy sources [15]. $\mathrm{CO}_{2}$ utilization to close the carbon-cycle is a key aspect for circular economy and the progressive substitution of fossil fuels [16]. Solar fuels and chemicals produced by electrocatalytic conversion of $\mathrm{CO}_{2}$ using renewable energy sources have the potential to contribute to decarbonize the energy system rapidly and on a large-scale [17-22], although there is still a debate on the target products for $\mathrm{CO}_{2}$ electrocatalytic reduction.

Various catalytic active elements have been reported for the electroreduction of $\mathrm{CO}_{2}$ including, for example, $\mathrm{Ag}, \mathrm{Au}, \mathrm{Pd}, \mathrm{Cu}, \mathrm{Ni}$, and $\mathrm{Pt}$ [23-37]. While often it is postulated that specific metals and planes are only needed for the selective electrocatalytic conversion of $\mathrm{CO}_{2}$, for example the formation of $\mathrm{C} 2$ products requiring the $\mathrm{Cu}(100)$ surface [38-40], recent results remarks that under controlled conditions of preparation and electrocatalytic testing (for example, enabling high surface coverage by chemisorbed $\mathrm{CO}_{2}[31,41]$ ), different metals become selective. There are many evidence that the $\mathrm{CO}_{2}$ activation and $\mathrm{C}-\mathrm{C}$ bond formation during the electrocatalytic reduction are determined by an intricate interplay between surface structure (both on the nano- and on the mesoscale), electrolyte effects ( $\mathrm{pH}$, buffer strength, ion effects) and mass transport conditions [42]. The formation of fractal-type [25] or disordered [43] nanostructures, surface strains [44] influence the path of $\mathrm{CO}_{2}$ electrocatalytic transformation and the effective surface current density [45] depending also on the $\mathrm{pH}$ near the catalyst surface. The back-diffusion rate of intermediates, such as the $\mathrm{CO}_{2}^{-}$formed by one-electron transfer to $\mathrm{CO}_{2}$ [46], depends on the effective surface potential seen by these intermediates. Additional factors are the amount of chemisorbed intermediates and their coupling mechanism [47], the presence of nanoconfinement in effects [48-50] or the possibility of

\footnotetext{
* Corresponding author at: Dept. ChiBioFarAm, University of Messina, V-le F. Stagno D’Alcontres 31, 98166, Messina, Italy.

E-mail addresses: mbhanu.iiit@gmail.com (B.C. Marepally), centi@unime.it (G. Centi).
} 
realizing multi-electron transfer [51]. They are among the concepts proposed in literature to tailor the paths of $\mathrm{CO}_{2}$ electrocatalytic conversion. However, an aspect investigated in a very limited extend is the possibility to modify the features of the electrocatalytic active metallic nanoparticles by decorating the nanoparticles with oxide nano-patches. This paper aims to investigate this aspect and analyse whether this effect could be used to improve the performances in the electrocatalytic reduction of $\mathrm{CO}_{2}$. In view of what commented above, evidencing that different metals could become selective in this reaction under specific conditions, we have studied supported nanoparticles of different metals, chosen especially among those less investigated in the electrocatalytic conversion of $\mathrm{CO}_{2}$, to remark how good electrocatalysts can be prepared also in these cases by proper preparation methods.

The issue is how to prepare effective and stable electrocatalytic nanoparticles having these characteristics. One interesting opportunity is offered from the organometallic (OM) synthesis of nanoparticles, which yields stable, monodispersed and small metallic nanoparticles (typically between 2 and $4 \mathrm{~nm}$ in diameter) [52-54], with Pt [55-57] and $\mathrm{Ru}[52,58]$ among the most studied metals. This method typically relies on the decomposition/reduction of an organometallic or inorganic precursor in the presence of a long chain silane or tin-based ligands. Such ligand allows the stabilization of the nanoparticles (NPs) via a strong non-exchangeable $\mathrm{M}-\mathrm{E}(\mathrm{E}=\mathrm{Si} / \mathrm{Sn})$ bond with the surface metal atom and ensures the solubility of the NPs solution in many solvents (both polar and apolar depending on the specific organic chain chosen). The resulting very stable colloids can generate metallic nanoparticles (NPs) on supports by simple impregnation. The use of an OM precursor as the metal source avoids the possible poisoning deriving from the use of metal salts as chlorides, nitrates. However, in OM route during the process of decomposition/reduction, part of the Si or Sn metal present in the ligands remains on the metal NPs forming (after exposure to air) oxide patches covering part of the surface of the metal NPs [52,54,59]. This occurs without the need to operate at high temperature under reduction conditions, as for strong-metal support interaction (SMSI), and in addition, occurs also using a conductive support such as carbon nanotubes, rather than using a reducible oxide support as $\mathrm{TiO}_{2}$. Other preparation methods (such as post-synthesis deposition of an oxide precursor) results less selective in forming small oxidic patches over the metal NPs with respect to the OM route based on our experience. The $\mathrm{OM}$ route is the preferable approach to obtain our preparation objective.

Here, to study supported NPs covered by small oxide patches, we investigate $\mathrm{Pt}, \mathrm{Ru}$, and $\mathrm{Fe}$ nanoparticles deposited on a conductive substrate (carbon nanotubes - CNTs) prepared by OM route using $n$ octylsilane as stabilizing ligand, comparing their behaviour with similar metallic NPs prepared via a conventional impregnation method.

The choice of these metals is motivated from various reasons: i) the availability of established methodologies to prepare them in a controlled way by the OM method, and the knowledge available on the formation of small oxidic patches over the metal NPs using this method, ii) our previous experience that $\mathrm{Fe}$ is a valuable metal for the electrocatalytic reduction of $\mathrm{CO}_{2}[25,60]$ and also that $\mathrm{Pt}$ becomes selective under specific conditions [31,41], while $\mathrm{Ru}$ was shown recently to have interesting properties in the reaction [61,62], and iii) the interest in investigating alternative metals than those more extensively investigated (such as $\mathrm{Cu}$ ), in view of the many evidences (summarized above) that the properties in the reduction of $\mathrm{CO}_{2}$ depend on many factors out of the specific nature of the metal itself. Therefore, valuable performances could be obtained also on metals traditionally scarcely investigated in literature for the electrocatalytic reduction of $\mathrm{CO}_{2}$. This will demonstrate in a more convincing way the role of this preparation parameter in boosting the electrocatalytic properties in $\mathrm{CO}_{2}$ conversion.

\section{Experimental}

\subsection{Materials and reagents}

Iron (III) nitrate nonahydrate $\left[\mathrm{Fe}\left(\mathrm{NO}_{3}\right)_{3}^{*} 9 \mathrm{H}_{2} \mathrm{O}\right]$, iron (III) acetyl acetonate $\left[\mathrm{Fe}\left(\mathrm{C}_{2} \mathrm{H}_{7} \mathrm{O}_{2}\right)_{3}\right.$ or $\left.\mathrm{Fe}(\mathrm{acac})_{3}\right]$, chloroplatinic acid hexahydrate $\left[\mathrm{H}_{2} \mathrm{PtCl}_{6} 6 \mathrm{H}_{2} \mathrm{O}\right]$, bis(dibenzylidene acetone) platinum [Pt(dba) $\left.)_{2}\right],(1,5-$ cycloctadiene)(1,3,5-cycloctatriene) ruthenium $\left[\mathrm{C}_{16} \mathrm{H}_{22} \mathrm{Ru}\right]$, ruthenium chloride hydrate $\left(\mathrm{RuCl}_{3}^{-} \mathrm{xH}_{2} \mathrm{O}\right)$, nitric acid $\left(\mathrm{HNO}_{3}, 65 \%\right)$, sulphuric acid $\left(\mathrm{H}_{2} \mathrm{SO}_{4}, 95 \%\right)$, absolute ethanol $(98 \%)$, potassium bicarbonate $\left(\mathrm{KHCO}_{3}\right.$, $99.7 \%$ ), octyl silane $\left[\mathrm{C}_{8} \mathrm{H}_{20} \mathrm{Si}\right]$ and Nafion perflourinated resin were obtained from Merck and used with no further purification. Solvents (hexane, toluene, tetrahydrofuran (THF)) were obtained from CarloErba and were dried and distilled before use.

Commercial carbon nanotubes (CNTs, PR-24-XT-PS) were bought from Pyrograf $₫$ and were pre-treated before use: a direct oxidative treatment using concentrated $\mathrm{HNO}_{3}$ was performed on the CNTs, introducing various surface oxygen functionalities [31,60].

Gas Diffusion layer (GDL 25 BC) was obtained from Sigracet ${ }^{\circledR}$. Nafion membrane (Nafion ${ }^{117}$ ) was obtained from Ion Power and was pre-treated before use [31].

\subsection{Analytical methods}

\subsubsection{Atomic absorption spectroscopy (AAS)}

The metal loading on the CNT substrate was determined using a Perkin-Elmer AAnalyst 200, atomic absorption spectrometer.

\subsection{2. $N_{2}$ adsorption/desorption at $77 \mathrm{~K}$}

Textural poperties (BET surface area porous volume, and BJH pore diameters) of the catalytic materials were determined using an ASAP 2020 Micromeritics system. To degas the samples, a pre-treatment was performed at $10^{-4} \mathrm{~Pa}, 150{ }^{\circ} \mathrm{C}$ for $2 \mathrm{~h}$.

\subsubsection{Gas chromatograph-mass spectrometer (GC-MS)}

The liquid products were analysed using a GC-MS (Thermo Trace 1310, ISQ Single Quadrupole MS, with a column Stabilwax). The gaseous products were analysed at fixed intervals with a GC (Agilent $7890 \mathrm{~A}$ ), equipped with a molecular sieve $5 \mathrm{~A}$ column and a thermal conductivity detector (TCD).

\subsubsection{Ion Chromatograph (IC)}

The liquid products were also analysed using an IC (IC Metrohm 940 professional, with a column Metrohm Organic Acids).

\subsubsection{High resolution transmission electron microscopy (HRTEM)}

HRTEM was performed on a MET JEOL 2100 FEF microscope at the "Centre Technologique des Microstructures", CT $\mu$ Villeurbanne, France; equipped with an energy-dispersive x-ray (EDX) analyser. Determination of size distribution of NPs by HRTEM images was made by using a software for image analysis and elaboration [63].

\subsubsection{Tomography analysis}

For the sample $\mathrm{Ru}_{\mathrm{OM}}{ }^{-} \mathrm{CNT}$, a series of tilted images was collected from $-67^{\circ}$ to $68^{\circ}$, with the Saxton scheme (variable angular step allowing to improve 3D reconstruction with a reduced number of images to preserve the beam sensitive structure of the sample). Images were acquired on a TEM JEOL JEM-2100 F equipped with a Gatan Ultrascan 1000 CCD camera. The used magnification is 60000 . For acquisitions and 3D reconstructions, the JEOL TEMography software package was used. 3D views of the reconstructed structures were obtained with ImageJ software [64].

\subsubsection{Scanning electron microscopy (SEM)}

All the SEM images were obtained by using Phenom ProX Scanning Electron Microscope (SEM). 


\subsubsection{X-Ray diffraction (XRD)}

XRD was performed to determine the crystal structure of the catalysts using a D2 Phaser Bruker diffractometer equipped with a $\mathrm{Cu}-\mathrm{K} \alpha$ radiation $(1.5406 \AA$ ) source operating at $30 \mathrm{kV}$ and $10 \mathrm{~mA}$. A scan rate of $0.025^{\circ} / \mathrm{s}$ with a $2 \theta$ range in $12^{\circ}$ to $100^{\circ}$ was used for data collection. All the XRD analysis were performed on reduced samples.

\subsubsection{X-Ray photoelectron spectra (XPS)}

Quantitative surface analysis was performed by XPS using PHI 5000 VersaProbe II spectrometer with a monochromatic Al-K $\alpha$ X-ray source operating at $100 \mathrm{~W}, 20 \mathrm{kV}$. The C-1 s binding energy of adventitious carbon $(284.9 \mathrm{eV})$ served as the reference.

\subsection{Preparation of the catalytic working electrodes}

\subsubsection{Synthesis of the colloidal solutions ( $P t, R u, F e)$ via organometallic route $(O M)$}

All experiments were carried out under argon atmosphere, using Schlenk tubes and glove-box techniques. The objective of the preparation was to prepare Pt, Fe and Ru NPs supported on CNTs, by using the OM method to obtain a stable colloidal solution that was then impregnated on CNTs. The target loading was $10 \mathrm{wt} . \%$, being the common loading used in preparing Me/CNTs electrocatalysts [60]. After deposition of the colloid, the wetted CNT is dried and reduced, then exposed to air. Under these conditions, the OM precursor and ligands decomposes, but part of the Si present in the precursor remain on the metal NPs, forming oxidic patches after exposure to air. For comparison, a conventional impregnation route using a typical metal salts aqueous solution was also prepared with the same metal loading (INORG route). However, as commented later in the results part, the amount of metal loading retained on the CNT substrate was largely lower in OM route with respect to INORG case. Thus, in the latter case, preparations by using a lower metal loading were also made.

\subsubsection{Synthesis of the Pt colloids}

Following the procedure reported in the literature [53,59], $34 \mathrm{mg}$ of bis(dibenzylidene acetone) platinum, $\mathrm{Pt}(\mathrm{dba})_{2}(51 \mu \mathrm{moles})$ was dissolved in $34 \mathrm{~mL}$ of tetrahydrofuran, THF, in a Schlenk tube. $20 \mu \mathrm{L}$ of $n$-octylsilane, $\mathrm{SiC}_{8} \mathrm{H}_{20}$, was added to the solution. A constant stirring ( $500 \mathrm{rpm}$ ) and 3 bars of $\mathrm{H}_{2}$ was maintained in the reactor. The setup was left overnight $(15 \mathrm{~h})$ to complete the reaction. The colloid was analysed by TEM and then used for impregnation after concentration (under vacuum) to $1 \mathrm{~mL}$ (equivalent to the pore volume of the CNTs to be impregnated, see below).

\subsubsection{Synthesis of the Ru colloids}

Following the procedure reported in the literature [52], $31 \mathrm{mg}$ of (1, 5-cycloctadiene)(1,3,5-cycloctatriene) ruthenium, $\mathrm{Ru}(\cot )(\operatorname{cod})$, $\mathrm{C}_{16} \mathrm{H}_{20} \mathrm{Ru}$ (equivalent to 0.10 mmoles) was dissolved in $36.5 \mathrm{~mL}$ of tetrahydrofuran, THF in a Schenk and $10 \mu \mathrm{L}$ of $n$-octyl silane, $\mathrm{SiC}_{8} \mathrm{H}_{20}$ was added to the final solution. Like Pt synthesis, $\mathrm{H}_{2}$ pressure and stirring conditions are maintained. The colloidal solution was concentrated in vacuum to $1 \mathrm{~mL}$ before impregnation on the CNT (see below).

\subsubsection{Synthesis of the Fe colloids}

The Fe NP synthesis was developed using a similar route than that used for preparing Pt- and Ru-NPs as described above. $60 \mathrm{mg}$ of iron (III) acetyl acetonate, $\mathrm{Fe}(\mathrm{acac})_{3}$ (equivalent to $0.18 \mathrm{mmol}$ ) was dissolved in a $60 \mathrm{~mL}$ mixture of toluene and hexane in 3:2 ratio. $n$-octylsilane, $\mathrm{SiC}_{8} \mathrm{H}_{20}$ $(30 \mu \mathrm{L})$ was added. The solution was stirred at $50{ }^{\circ} \mathrm{C}$ under $\mathrm{H}_{2}$ pressure (3 bar). The setup was left overnight to complete the reaction. The NP colloids were analysed by TEM. The final colloidal solution was concentrated in vacuum to $1 \mathrm{~mL}$ before deposition on CNTs.
2.3.5. Preparation of the electrocatalyst by deposition of the metal nanoparticles (Pt, $\mathrm{Ru}, \mathrm{Fe}$ ) on carbon nanotubes (CNTs)

\subsubsection{Method 1. Deposition of NPs using the colloidal solutions (OM} route)

The vacuum-concentrated metal colloidal solutions $(1 \mathrm{~mL})$ described in the previous paragraph were immediately impregnated onto $100 \mathrm{mg}$ CNTs by incipient wetness impregnation technique, i.e. by adding the solution drop by drop until the carbon substrate got slightly wet. The wetted CNTs were then dried in the oven at a temperature slightly above the boiling point of solvent used $\left(70^{\circ} \mathrm{C}\right.$ for THF and $115^{\circ} \mathrm{C}$ for Toluene). This process was repeated until the colloidal solution was evaporated. The final sample was dried overnight in an oven at $70^{\circ} \mathrm{C}$ or $115{ }^{\circ} \mathrm{C}$ for THF and toluene, respectively. Finally, the electrocatalysts were reduced for $2 \mathrm{~h}$ at $350{ }^{\circ} \mathrm{C}$ (ramp rate $\left.6{ }^{\circ} \mathrm{C} / \mathrm{min}\right)$ under $\mathrm{H}_{2}$ flow $(25 \mathrm{~mL} / \mathrm{min})$.

2.3.5.2. Method 2. In situ preparation of supported metallic NPs using inorganic salts (INORG route)

The precursor, $\mathrm{Fe}\left(\mathrm{NO}_{3}\right)_{3}^{*} 9 \mathrm{H}_{2} \mathrm{O}, \mathrm{RuCl}_{3} \mathrm{xH}_{2} \mathrm{O}$ or $\mathrm{H}_{2} \mathrm{PtCl}_{6}^{\circ} 6 \mathrm{H}_{2} \mathrm{O}(72 \mathrm{mg}$, $26 \mathrm{mg}$ and $27 \mathrm{mg}$, respectively, equivalent to $10 \mathrm{wt}$. \% of metal regarding $100 \mathrm{mg}$ of $\mathrm{CNT}$ ), was added to an EtOH : $\mathrm{H}_{2} \mathrm{O}$ mixture (1: 0.2 $\mathrm{mL}$, total volume $1.2 \mathrm{~mL}$ ) and sonicated for $10 \mathrm{~min}$. The motivation of using this amount of $10 \mathrm{wt} . \%$ of metal is that this amount is that typically used in preparing electrocatalysts for $\mathrm{CO}_{2}$ reduction [60], and because the total amount of metal in the impregnation solution is the same of that present in the $1 \mathrm{~mL}$ colloidal solution used in OM method. Incipient wetness impregnation [60] was used to impregnate the solution onto the CNTs that were further dried for $24 \mathrm{~h}$ at $80^{\circ} \mathrm{C}$. The solid was then reduced at $350{ }^{\circ} \mathrm{C}$ (ramp rate $6{ }^{\circ} \mathrm{C} / \mathrm{min}$ ) for $2 \mathrm{~h}$ under a constant $\mathrm{H}_{2}$ flow $(25 \mathrm{~mL} / \mathrm{min})$. A second batch of catalysts with only $2 \mathrm{wt} \%$ of metal loading was synthesized following the same protocol and using the same metal precursors. The reason of this second batch of catalysts with reduced loading is that in OM route the effective amount of metal retained by the electrocatalyst was lower, and most of the cases around this 2 wt.\% value.

\subsubsection{Preparation of the GDL (gas diffusion layer)-type electrodes}

The electrocatalysts described in the previous section were mixed with ethanol (5 mL), containing 1-drop of liquid Nafion (adhesive agent) and sonicated for 30 min to form a dark ink. The ink was transferred onto GDL with sequential deposition-drying cycles. In detail, the ink was transferred on to the GDL by spray or drop-by-drop deposition, thus forming a layer, then dried for $5 \mathrm{~min}$ at $100{ }^{\circ} \mathrm{C}$, repeating the cycle until using all the ink.

All the procedures of preparation are summarized in Fig. 1.

These acronyms will be used hereinafter to describe the electrocatalysts: $\mathrm{Pt}_{\mathrm{OM}^{-}} \mathrm{CNT}$, $\mathrm{Ru}_{\mathrm{OM}}-\mathrm{CNT}$ and $\mathrm{Fe}_{\mathrm{OM}^{-}} \mathrm{CNT}$, or $\mathrm{Pt}_{\mathrm{INORG}}-\mathrm{CNT}, \mathrm{Ru}_{\mathrm{IN}}$ -

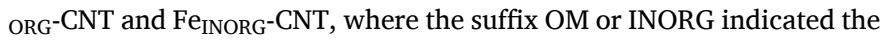
related preparation routes.

\subsection{Electrocatalytic (EC) tests}

The electrocatalytic cell has a compact three-electrode configuration with minimized distance between the electrodes to reduce the resistances and uses the same electrolyte $\left(0.5 \mathrm{M} \mathrm{KHCO}_{3}\right.$ saturated with bubbling $\mathrm{CO}_{2}$ ) on both hemicells, in order to avoid the formation of a chemical potential. The cathodic hemicells, where $\mathrm{CO}_{2}$ is reduced, operates with external recirculation to a reservoir. Fig. S1 (Supplementary Info) reports the scheme for the reactor and the details of the analytical aspects in relation to product analysis. Further details on the cell and experimental procedure were also reported previously [25,27, $41,60,65]$.

The tests in the continuous electrocatalytic reactor were made usually for $4 \mathrm{~h}$, monitoring the performances as a function of time on stream. However, being necessary at the beginning about $30 \mathrm{~min}$ of time 

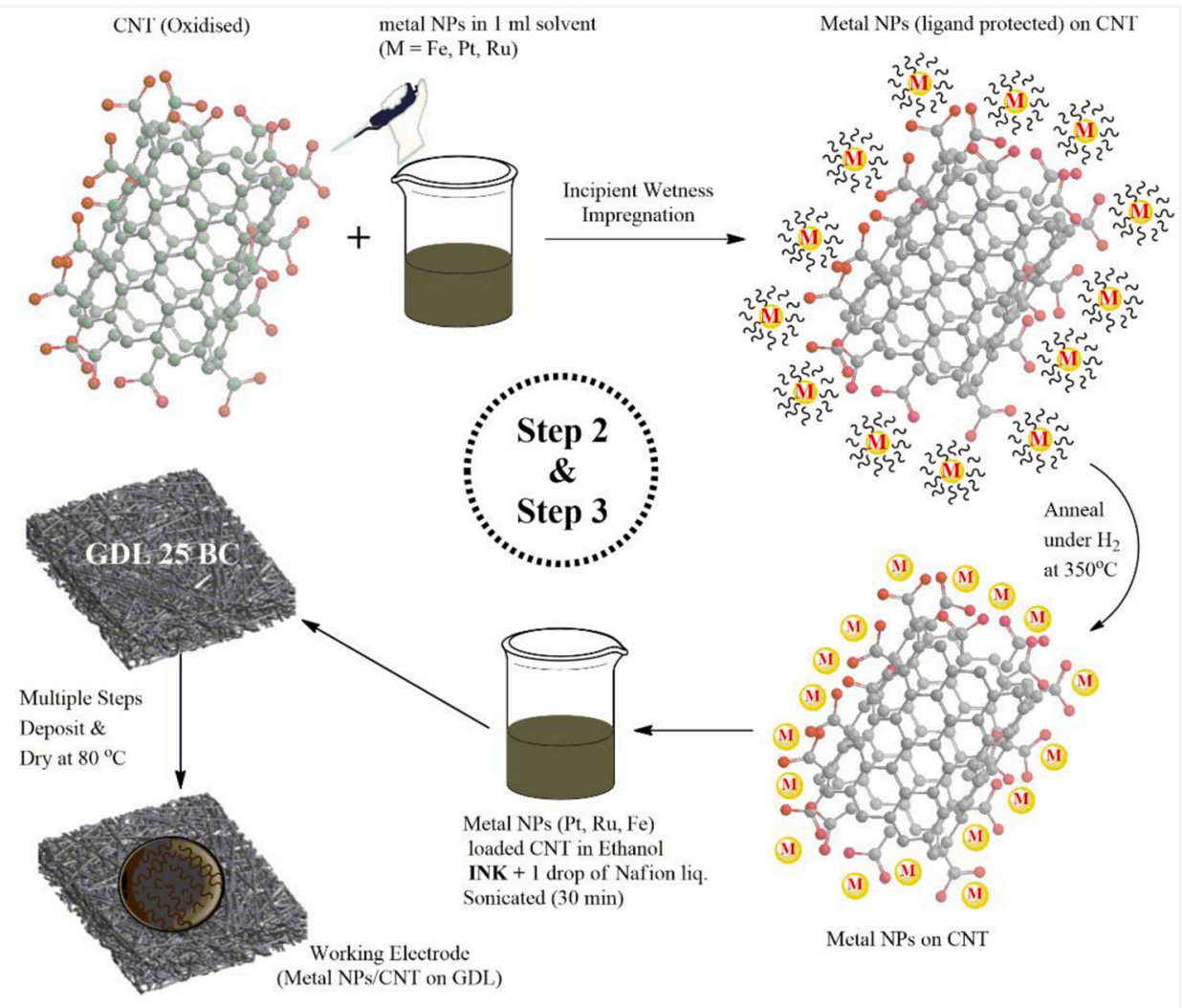

Fig. 1. Scheme of the deposition process of the colloidal NPs solutions to prepare the working electrode.

to establish the equilibrium in the cell, the data for this initial part were not considered. After this initial change (see Fig. S7 Supplementary Info), the activity and current intensity remained constant indicating a stable behaviour. Tests also for longer times (up to $20 \mathrm{~h}$ ) were made, not evidencing a decay of the performances. Analysis of the electrolyte by atomic adsorption spectroscopy (AA) revealed the absence of significant leaching. After this initial equilibration time $(30 \mathrm{~min})$, the analysis of liquid and gas phase products was made by gas chromatography as described in the Supplementary Info. The data reported here refer to the average value determined in $4 \mathrm{~h}$ experiments, mediating the different analytical data obtained after this initial equilibration time. The error observed was below $5 \%$.

Reproducibility experiments, e.g., repeating the tests with a new batch of the electrocatalyst, were also performed, not revealing significant issues of reproducibility.

Different indexes of the electrocatalytic behaviour were used to analyse in detail various aspects of the results. These indexes were the following:

- Normalized productivity with respect to current density $\left(\mu \mathrm{mol} h^{-1} \cdot A^{-1}\right)$ : the experimental value of rate of product(s) formation ( $\mu \mathrm{mol} \mathrm{h}-1)$ divided by the experimental current intensity in A;

- cumulative productivity $\left(C_{S U M}\right)$ : total efficiency of products formation in the $\mathrm{CO}_{2}$ electrocatalytic reduction (with respect to $\mathrm{H}_{2}$ formation);

- $C_{1-e q}:$ weighted sum of products with respect to the number of carbon atoms involved to consider that longer chain molecules require more $\mathrm{CO}_{2}$ molecules to be converted. This $\mathrm{C}_{1 \text {-eq }}$ index is an indication of the total productivity normalized to equivalent $\mathrm{C} 1$ products;

- $C 1 / C_{1-e q}$ ratio: the relative formation of $C_{1}$ products with respect to $\mathrm{C}_{1-\mathrm{eq}}$, the total productivity normalized to equivalent $\mathrm{C}_{1}$ products. This index indicates the fraction of products with one carbon atom with respect to the total productivity to carbon products (weighted to consider the different number of carbon atoms present in the products);

- Relative carbon selectivity: the relative distribution of carbon products in $\mathrm{CO}_{2}$ electrocatalytic reduction weighted with respect to the number of carbon atoms in the product;

- normalized turnover frequency (nTOF): the normalized productivity divided by the number of surface atoms in moles ( $\mathrm{M}_{\text {surf: }}$ see Table 2 ) estimated for the metallic NPs in the electrocatalysts;

- normalized TOF to current intensity: TOF $\left(\mathrm{h}^{-1}\right)$ divided the current intensity (A);

- $\mathrm{TOF}_{\mathrm{OM}} / \mathrm{TOF}_{\text {INORG: }}$ ratio of TOF determined for samples prepared by the OM route with respect to the equivalent metal samples prepared by INORG route;

- Faradaic Efficiency (FE) to carbon products: total number of electrons used in the conversion of products with respect to the total charge passed, i.e. product yields (mol) x number of electron) / (charged passed (Q) x F.

\section{Results}

\subsection{Preparation and characterization of the electrocatalysts}

Two synthetic routes were used to prepare the Ru-, Pt- or Fe-based electrocatalysts, briefly indicated as inorganic route (INORG) and organometallic route (OM). The motivations for the selection of these metals and why to use an OM route were indicated in the introduction. Scheme 1 summarizes the methodology used in the OM route, being the less common. In both routes, CNT functionalized by oxidative treatment (see experimental part) are used as substrate to deposit the metal nanoparticles, and then these electrocatalysts are used to prepare the electrode by deposition on GDL. The main difference between INORG and $\mathrm{OM}$ routes is that in the first case, a solution containing inorganic salt precursors is used, while a colloidal solution containing small 

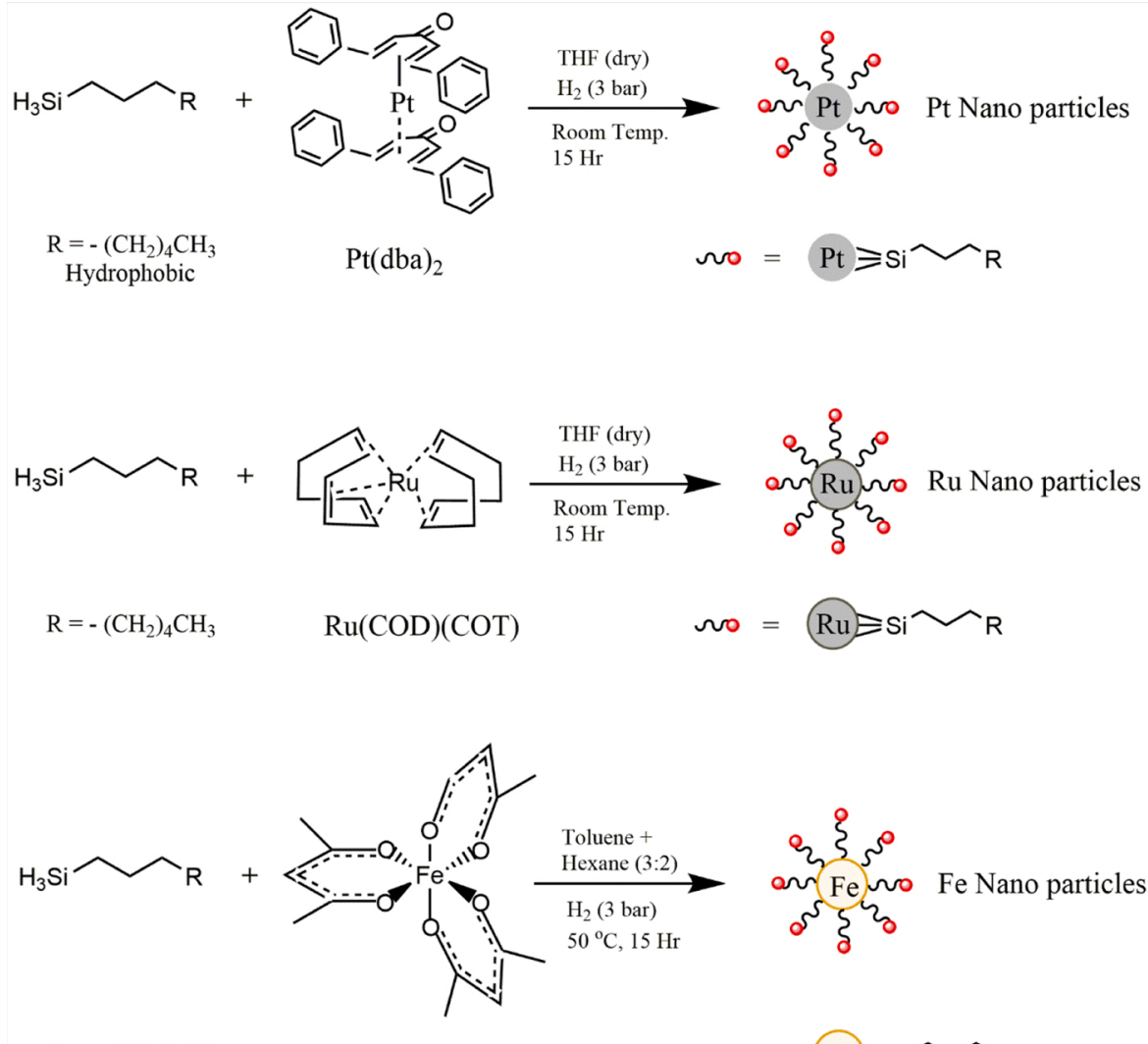

$$
\mathrm{R}=-\left(\mathrm{CH}_{2}\right)_{4} \mathrm{CH}_{3} \quad \mathrm{Fe}(\text { acac })_{3}
$$

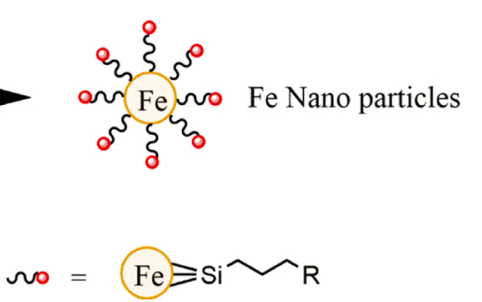

an Fe no Fe Nano particles रुद

$\sim_{0}=\left(\mathrm{Fe}=\mathrm{Si} \sim \hat{R}_{\mathrm{R}}\right.$

Scheme 1. Reaction scheme of OM route using colloidal solution of (i) Pt NPs from Pt(dba) 2 , (ii) Ru NPs from Ru(cod)(cot), (iii) Fe NPs from Fe(acac) 3 .

metallic NPs containing surface octyl silicon fragments is used in the second case. The use of a colloidal solution (OM route) leads in general to smaller and size-controlled NPs with respect to those obtained in the INORG route, but as shown later, the weaker interaction between the colloidal nanoparticles and the carbon substrate leads to a lower amount of metal retained by CNT substrate after completing the preparation in OM with respect to the INORG case.

The analysis by TEM of the colloidal starting solutions for impregnation in the OM route indicates the presence of small and narrowly dispersed nanoparticles for all the metallic phases. The decomposition of the platinum adduct $\mathrm{Pt}(\mathrm{dba})_{2}$ and the organometallic complex Ru(COD) (COT) in presence of $n$-octylsilane under dihydrogen pressure (see Scheme 1) leads to well-dispersed stable NPs of $0.8( \pm 0.3) \mathrm{nm}$ and 0.9 $( \pm 0.3) \mathrm{nm}$ in solution (see Supplementary Info, Fig. S2) respectively. Slightly larger sized nanoparticles were observed in the case of iron, which are still relatively small in size $[2.0( \pm 0.5) \mathrm{nm}]$. The progress of the reaction can be observed through the colour change of the solution, which turns dark brownish black for the Pt and Ru cases and dark reddish orange for Fe.

For the analysis of the electrocatalysts after the deposition of the colloidal NPs, followed by drying, reduction and exposition to air, HRTEM (high-resolution transmission electron microscopy, bright field) and HAADF-STEM (annular dark field image for scanning transmission electron microscope) methods were used. The results are summarized in Fig. 2 and evidence a uniform size distribution for Pt, Fe, and Ru NPs on CNTs with a NPs size range of $1-5 \mathrm{~nm}$. The mean NP sizes are 1.1, 1.3 and $4.1 \mathrm{~nm}$ for Pt, Ru and Fe, respectively. Reminding that the starting colloidal solutions have a mean NP size of $0.8,0.9$ and $2.0 \mathrm{~nm}$, respectively, a small increase in size is observed with a slightly broader size distribution especially for Fe NPs after deposition on CNTs.

For the INORG route, larger NPs with a broader size distribution were observed. This is clearly evidenced in Table 1 reporting the mean size distributions, the standard deviation and the range values of all NPs deposited on CNT after calcination and reduction. These data were collected from high-resolution transmission electron micrographs (HRTEM) with size distribution determined by image software elaboration. Fig. 3 reports TEM images for $\mathrm{Pt}_{\mathrm{INORG}}-\mathrm{CNT}, \mathrm{Ru}_{\mathrm{INORG}}-\mathrm{CNT}$ and $\mathrm{Fe}_{\text {INORG-CNT electrocatalysts and the related size distribution histogram }}$ for all metallic NPs. The NPs average size and size distribution are 7.8 ( \pm 3.8$), 2.6( \pm 1.2)$, and $9.3( \pm 3.1) \mathrm{nm}$, for Pt, Ru and Fe, respectively.

As a further support to this indication, Fig. S3 (Supplementary Info) reports TEM data for a Ru sample prepared by the INORG route with a metal loading of $2 \%$, thus closer to that of samples prepared by the OM route. In this case, smaller NPs are observed, although slightly larger than those obtained by the OM route. In addition, NPs size distribution is also broader.

To clarify whether the NPs are inside or outside the CNTs, a tomography analysis for the $\mathrm{Ru}_{\mathrm{OM}}$-CNT sample was performed (Fig. 4). The ruthenium-based system was chosen for its enhanced performances in terms of productivity and selectivity as discussed later. Tomography analysis reveals Ru NPs both on the inner and outer walls of the CNTs. Fig. 4 (c) shows two circular distributions of Ru NPs: one inside and one outside the nanotube. Fig. 4 (d) shows an image sequence of the Ru NPs on CNTs.

A quantitative surface analysis of the $\mathrm{Pt}_{\mathrm{OM}^{-}}{ }^{-\mathrm{CNT}}, \mathrm{Ru}_{\mathrm{OM}^{-}} \mathrm{CNT}$ and $\mathrm{Fe}_{\mathrm{OM}}$-CNT samples was made by X-Ray photoelectron spectra (XPS) (see Fig. S4 in Supplementary Info). The XPS spectra show that the Pt oxidation state is mainly $\mathrm{Pt}^{\circ}$ with a characteristic peak at $71.5 \mathrm{eV}$. However, a small peak of Pt (IV) is also observed at $75 \mathrm{eV}$ (by deconvolution, see Supplementary Info). The XPS spectrum of Ru $\mathrm{RM}^{-\mathrm{CNT}}$ shows the characteristic binding energies of Ru 3p at $461.65 \mathrm{eV}$. Ru is only in the metallic state $\left(\mathrm{Ru}^{\circ}\right)$ as evidenced by the peak at $280.4 \mathrm{eV}$ (characteristic peak of the Ru 3d). The same XPS spectrum is observed also in the $\mathrm{Ru}_{\mathrm{INORG}}-\mathrm{CNT}$ samples, indicating also the presence of only 


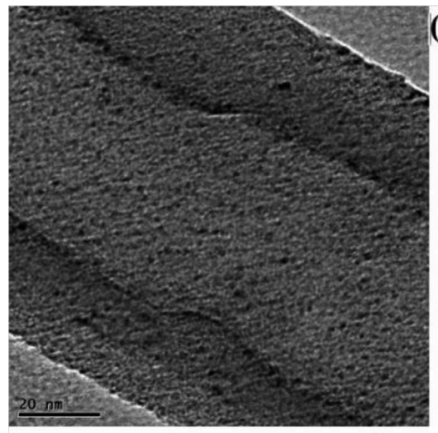

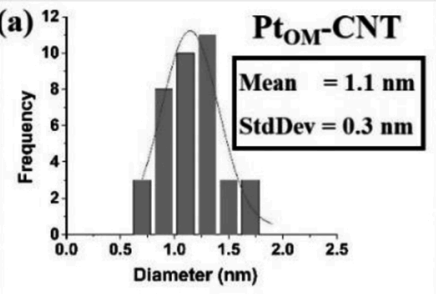

Min. Particle Size $=0.7$ nm

Max. Particle Size $=1.8 \mathrm{~nm}$

Avg. Size Range $=0.8 \mathrm{~nm}-1.4 \mathrm{~nm}$

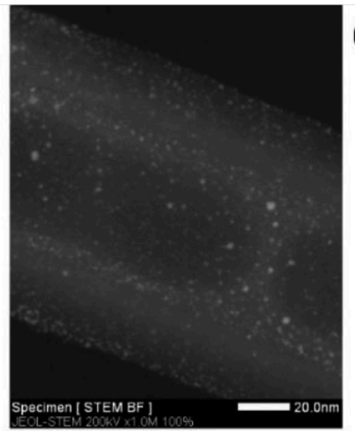

(b)

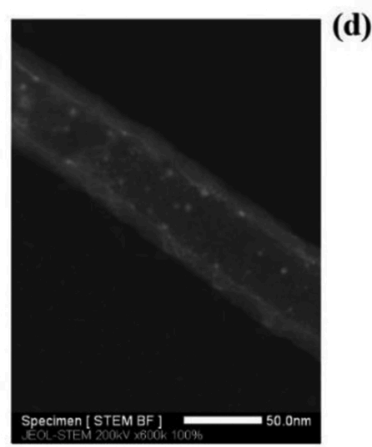

(d)

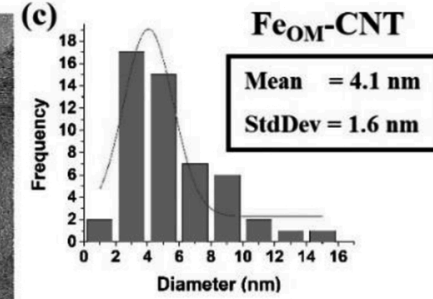

Min. Particle Size $=1.6$ nm

Max. Particle Size $=15.3 \mathrm{~nm}$

Avg. Size Range $=2.1 \mathrm{~nm}-6.0 \mathrm{~nm}$

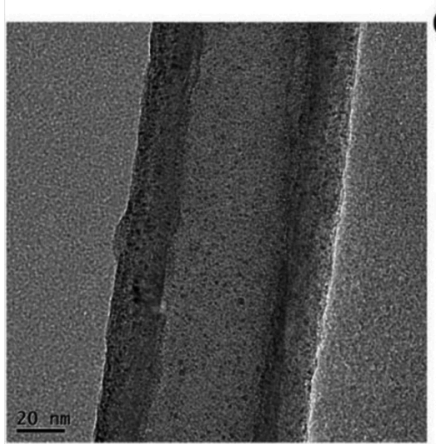

\section{(e) ${ }_{12} \quad \mathrm{Ru}_{\mathrm{OM}^{-}}-\mathrm{CNT}$}

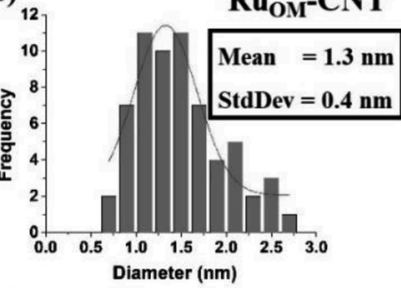

Min. Particle Size $=0.7 \mathrm{~nm}$

Max. Particle Size $=2.7 \mathrm{~nm}$

Avg. Size Range $=0.95$ nm -1.7 nm

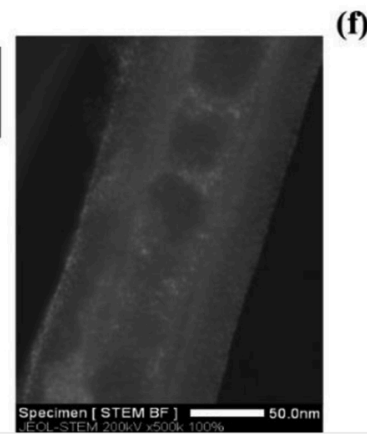

Fig. 2. TEM and STEM images of $\mathrm{Pt}_{\mathrm{OM}^{-}} \mathrm{CNT}$, $\mathrm{Ru}_{\mathrm{OM}}-\mathrm{CNT}$ and $\mathrm{Fe}_{\mathrm{OM}^{-}} \mathrm{CNT}$ and histogram of the size distribution of metallic NPs.

Table 1

Size distributions of $\mathrm{M}=\mathrm{Pt}, \mathrm{Fe}$ and Ru NPs deposited on CNT for INOR and OM routes.

\begin{tabular}{|c|c|c|c|}
\hline \multirow{2}{*}{ Electro-catalyst } & \multicolumn{3}{|c|}{ Particle Size (nm) } \\
\hline & Mean & Standard Deviation & Min. - Max. \\
\hline $\mathrm{Pt}_{\mathrm{INORG}}-\mathrm{CNT}$ & 7.8 & 3.8 & $2.2-32.0$ \\
\hline $\mathrm{Fe}_{\text {INORG }}-\mathrm{CNT}$ & 9.3 & 3.1 & $3.2-25.4$ \\
\hline $\mathrm{Ru}_{\text {INORG }}-\mathrm{CNT}$ & 2.6 & 1.2 & $1.5-12.5$ \\
\hline $\mathrm{Ru}_{\text {INORG }}-\mathrm{CNT} 2 \%$ & 1.8 & 0.6 & $0.8-6.5$ \\
\hline $\mathrm{Pt}_{\mathrm{OM}^{-}}{ }^{\mathrm{CNT}}$ & 1.1 & 0.3 & $0.7-1.8$ \\
\hline $\mathrm{Fe}_{\mathrm{OM}}-\mathrm{CNT}$ & 4.1 & 1.6 & $1.5-15.3$ \\
\hline $\mathrm{Ru}_{\mathrm{OM}^{-}}-\mathrm{CNT}$ & 1.3 & 0.4 & $0.7-2.7$ \\
\hline
\end{tabular}

$\mathrm{Ru}^{\circ}$. Conversely, the $\mathrm{Fe}_{\mathrm{OM}^{-}}$CNT spectrum displays peaks at $711.85 \mathrm{eV}$ and $725.50 \mathrm{eV}$, which correspond to the characteristic binding energies (B.E.) for the $\mathrm{Fe}^{3+}$ species, further confirmed by satellite peaks at 716.25 $\mathrm{eV}$ and $731.10 \mathrm{eV}$. $\mathrm{Fe}_{\mathrm{OM}^{-}}$CNT XPS spectra (Fig. S4, Supplementary Info) also evidence metal oxide signatures not observed for $\mathrm{Pt}$ and $\mathrm{Ru}$, consistently with the stronger stability against oxidation for these noble metals. In addition, a peak corresponding to metallic iron in the XRD spectra for $\mathrm{Fe}_{\mathrm{OM}}$ - $\mathrm{CNT}$ could be evidence, indicating a metallic core under the oxidized surface.

The X-Ray diffractograms of $\mathrm{Pt}_{\mathrm{OM}^{-}}{ }^{-\mathrm{CNT}}, \mathrm{Ru}_{\mathrm{OM}^{-}} \mathrm{CNT}$ and $\mathrm{Fe}_{\mathrm{OM}^{-}} \mathrm{CNT}$ and those of $\mathrm{Pt}_{\text {INORG-CNT (Fig. S5 - Supplementary Info), are dominated }}$
Table 2

Metal loading, dispersion $\left(\chi_{\mathrm{SA}}\right)$, amount of surface metal atoms (in $\left.\mu \mathrm{mol}\right)$ and textural properties for the Pt-, Fe-, Ru-CNT electrocatalysts prepared by OM and INORG routes.

\begin{tabular}{|c|c|c|c|c|c|c|}
\hline \multirow[b]{2}{*}{$\begin{array}{l}\text { Electro- } \\
\text { catalyst }\end{array}$} & \multirow[b]{2}{*}{$\begin{array}{l}\% \\
\text { wt. }\end{array}$} & \multirow[b]{2}{*}{$\begin{array}{l}\text { Fraction of } \\
\text { surface metal } \\
\text { atoms }\left(\chi_{\mathrm{SA}}\right)\end{array}$} & \multirow[b]{2}{*}{$\begin{array}{l}M_{\text {surf }} \\
(\mu \mathrm{mol})\end{array}$} & \multicolumn{3}{|c|}{ BET Analysis } \\
\hline & & & & $\begin{array}{l}\mathrm{A}_{\mathrm{BET}} \\
\left(\mathrm{m}^{2}\right. \\
\left.\mathrm{g}^{-1}\right)\end{array}$ & $\begin{array}{l}\mathrm{V}_{\mathrm{m}} \\
\left(\mathrm{cm}^{3}\right. \\
\left.\mathrm{g}^{-1}\right)\end{array}$ & $\begin{array}{l}\text { Average pore } \\
\text { diameter } \\
\text { BJH (nm) }\end{array}$ \\
\hline $\mathrm{CNT}_{\mathrm{ox}}$ & - & & & 23.1 & 5.3 & 11.4 \\
\hline $\begin{array}{c}\mathrm{Pt}_{\mathrm{INORG}^{-}} \\
\mathrm{CNT}\end{array}$ & 9.3 & 0.14 & 76 & 23.6 & 5.4 & 11.3 \\
\hline $\begin{array}{c}\mathrm{Fe}_{\text {INORG- }} \\
\mathrm{CNT}\end{array}$ & 8.8 & 0.09 & 158 & 63.8 & 14.6 & 9.2 \\
\hline $\begin{array}{c}\mathrm{Ru}_{\mathrm{INORG}^{-}} \\
\mathrm{CNT}\end{array}$ & 9.0 & 0.28 & 409 & 47.2 & 10.8 & 19.1 \\
\hline $\begin{array}{r}\mathrm{Ru}_{\text {INORG }^{-}} \\
\text {CNT2 } \%\end{array}$ & 2.0 & 0.36 & 119 & n.a. & n.a & n.a. \\
\hline $\mathrm{Pt}_{\mathrm{OM}^{-}}{ }^{-\mathrm{CNT}}$ & 2.0 & 0.72 & 84 & 21.2 & 4.8 & 13.0 \\
\hline $\begin{array}{l}\mathrm{Fe}_{\mathrm{OM}^{-}} \\
\mathrm{CNT}\end{array}$ & 5.2 & 0.20 & 289 & 50.5 & 11.6 & 12.1 \\
\hline $\begin{array}{r}\mathrm{Ru}_{\mathrm{OM}^{-}} \\
\mathrm{CNT}\end{array}$ & 2.0 & 0.50 & 148 & 40.9 & 9.4 & 11.2 \\
\hline
\end{tabular}

by the reflection at $2 \theta=26.45^{\circ}$ assigned to 002 planes of the CNT support. The Pt-based samples exhibit peaks at $2 \theta=39.85^{\circ}$ and $46.43^{\circ}$, corresponding to the (111) and (200) planes of metallic Pt (FCC). For the 

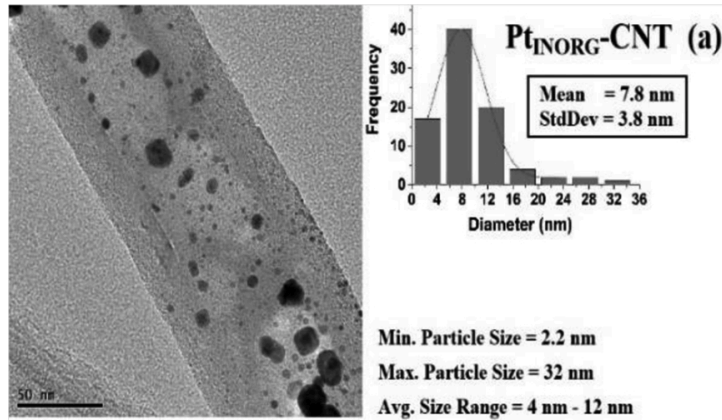

Min. Particle Size $=2.2 \mathrm{~nm}$ Max. Particle Size $=32 \mathrm{~nm}$ Avg. Size Range $=4$ nm - 12 nm
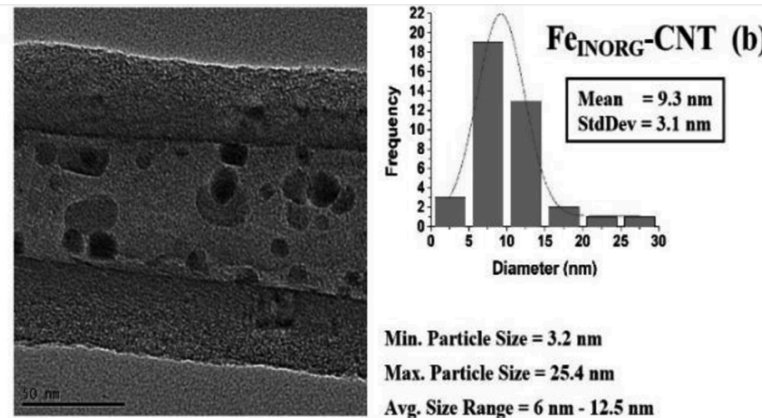

Min. Particle Size $=3.2 \mathrm{~nm}$

Max. Particle Size $=25.4 \mathrm{~nm}$

Avg. Size Range $=6 \mathrm{~nm}-12.5 \mathrm{~nm}$
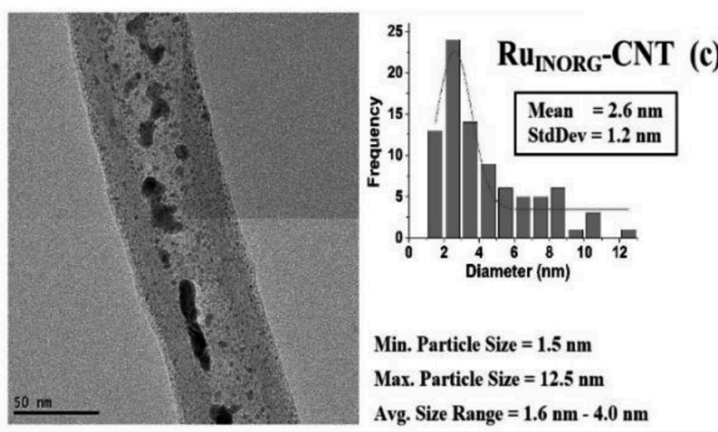

Min. Particle Size $=1.5 \mathrm{~nm}$

Max. Particle Size $=12.5 \mathrm{~nm}$

Avg. Size Range $=1.6 \mathrm{~nm}-4.0 \mathrm{~nm}$

Fig. 3. TEM images of $\mathrm{Pt}_{\mathrm{INORG}}-\mathrm{CNT}$, $\mathrm{Ru}_{\mathrm{Pt}} \mathrm{t}_{\mathrm{INORG}}-\mathrm{CNT}$ and $\mathrm{Fe} \mathrm{Pt}_{\mathrm{INORG}}-\mathrm{CNT}$ and histogram of the size distribution of metallic NPs.
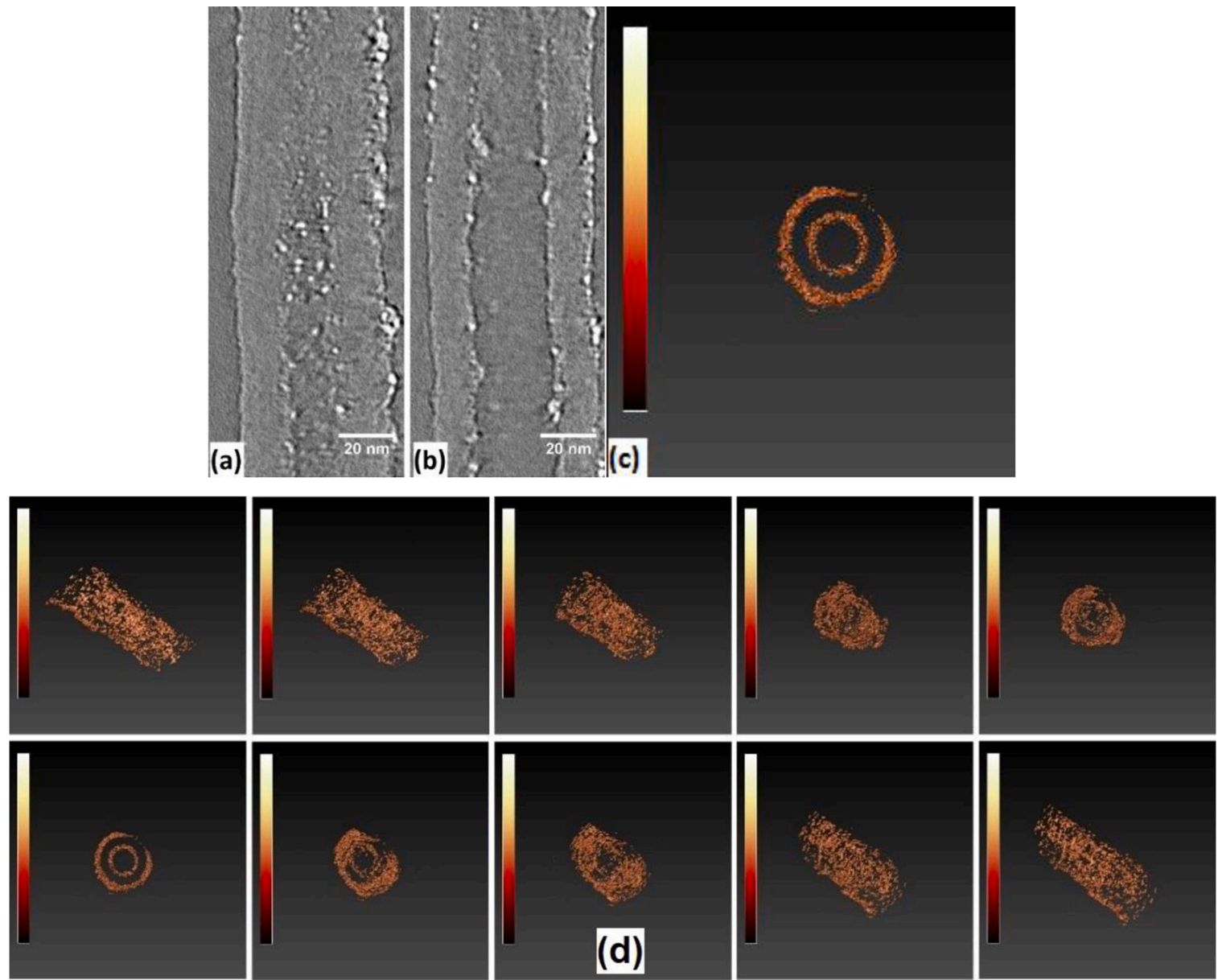

Fig. 4. Tomography analysis for Ru $\mathrm{OM}^{-} \mathrm{CNT}$ sample: (a) Lateral view of the Ru NPs at the nanotube mouth; (b) Lateral view of the Ru NPs at different depth of CNT; (c) Orthogonal or Top-view of the Ru NPs distribution; (d) Sequence of images giving a 3D view of the Ru NPs distribution. 
ruthenium-based samples, the peak found at $2 \theta=44.37^{\circ}$ corresponds to the (101) plane of Ru metal (HCP). In the Fe-based samples, the diffraction peak at $2 \theta=44.88^{\circ}$ corresponds to the (110) plane of $\mathrm{Fe}$ metal (BCC). The most noticeable difference between the two sets of XRay diffractograms (OM versus INORG routes) is the width of the metalrelated diffraction peaks. These are generally sharper for the NPs arising from the inorganic route regarding those from the organometallic route, in line with the larger NPs size for the former.

The metal loading on the CNT substrates was determined by atomic absorption spectroscopy. The metal loading was chosen analogous to that of the electrocatalysts for PEM fuel cells, which usually is in the $10-20 \%$ wt range corresponding to $\sim 0.5 \mathrm{mg} / \mathrm{cm}^{2}$ in the final catalyst. The experimental metal loading on the CNTs is only slightly lower than the nominal loading of $10 \mathrm{wt} . \%$, with values of ca. $9 \%$ for the samples obtained from inorganic salts (see Table 2). But in OM route, although the target loading was like that of the INORG route, the effective loading was significantly lower, around $2 \%$ for Pt and Ru samples, and $5 \%$ for $\mathrm{Fe}$ sample. In the OM route, after preparation of the colloidal solution, this was deposited by impregnation on the electrocatalyst, but likely there is a weak interaction between the colloidal nanoparticles and the support. Therefore, the effective amount remaining anchored to the support, likely at functionalized sites, is lower than the nominal value. This is often observed for preparations by colloidal particles deposition. This interaction depends on the characteristics of the colloidal nanoparticles and the difference between noble metal and Fe cases. Due to the large difference in loading of Pt or Ru on CNTs by using INORG and OM routes, a further Ru-CNT sample was prepared by INORG route with a loading closer to that prepared by the OM route $\left(\mathrm{Ru}_{\mathrm{INORG}}-\mathrm{CNT} 2 \%\right)$. Based on established models, the fraction of surface atoms $\left(\chi_{S A}\right)$ and the corresponding $\mu \mathrm{mol}$ of surface metal atoms for each sample were estimated and reported in Table 2, (see also Table S1 in Supplementary Info for more details on how $\chi_{S A}$ was calculated).

Table 2 summarizes the textural properties of these electrocatalysts. The corresponding $\mathrm{N}_{2}$ adsorption/desorption isotherms are reported in
Fig. S6 (Supplementary Info). An increase in the surface area and pore volume with respect to $\mathrm{CNT}_{\text {ox }}$ can be noted (Area, Volume $-\mathrm{CNT}_{\text {ox }}=$ 23.1, 5.3; $\mathrm{Ru}_{\mathrm{OM}^{-}}{ }^{-\mathrm{CNT}}=40.9,9.4$ in standard units).

\subsection{Electrocatalytic performances}

The electrocatalytic tests were made in a compact design continuous apparatus, which scheme is presented in Fig. S1 (Supplementary Info). The current profiles monitored during $\mathrm{CO}_{2}$ reduction reactions $\left(\mathrm{CO}_{2} \mathrm{RR}\right)$ for $\mathrm{M}_{\mathrm{OM}}{ }^{-} \mathrm{CNT}$ and $\mathrm{M}_{\mathrm{INORG}}-\mathrm{CNT}(\mathrm{M}=\mathrm{Fe}$, Pt and $\mathrm{Ru}$ ) electrocatalyst series (see Fig. S7 in Supplementary Info) indicated that after an initial change (in the first $30 \mathrm{~min}$ of time on stream) related to the establishment of the equilibrium in the cell (thus normal physico-chemical and engineering effects not depending on the electrocatalyst itself), a constant current is reached and maintained for at least $4 \mathrm{~h}$ of continuous electrocatalytic tests. This indicates the stability of the performances during the experiments. Longer term tests, up to $20 \mathrm{~h}$ in continuous mode, were also made confirming stability. The leaching of the metal was also analysed, not evidencing significant leaching, in accordance with stability of the current profile. Reproducibility of the results was also checked testing different batches of the prepared electrocatalysts.

The overview of the catalytic performances (at a constant applied potential of $-2.0 \mathrm{~V}$ ) is shown in Table 3. The effect of the applied potential was preliminary analysed and based on these preliminary tests, the applied potential of $-2.0 \mathrm{~V}$ was chosen as the best compromise between productivity and selectivity in $\mathrm{CO}_{2}$ electrocatalytic conversion. The experimental part describes the modalities in which tests were made, the error associated to measurements and reproducibility of the results in repeated tests, together with the different indexes used to describe the catalytic behaviour. We consider necessary to use a wider set of modalities to analyse the electrocatalytic data with respect to the conventional indexes used in the electrocatalytic behaviour (as product yield and Faradaic efficiency), because the latter are not able to compare properly the behaviour of the different samples we have investigated.

Table 3

Productivity $\left(\mu \mathrm{mol} \cdot \mathrm{h}^{-1} \cdot \mathrm{A}^{-1}\right)$ and TOF per surface metal atom $\left(\mathrm{M}_{\text {surf }}\right)$ (normalized to current observed during $\mathrm{CO}_{2} \mathrm{RR}$ ) for the the Pt-, Fe-, Ru-CNT electrocatalyst series prepared by OM and INORG routes. The cumulative productivity $\left(\mathrm{C}_{\mathrm{SuM}}\right)$, as index of the total efficiency of products formation in the $\mathrm{CO}_{2}$ electrocatalytic reduction (with respect to $\mathrm{H}_{2}$ formation) and $\mathrm{C}_{1 \text {-eq, }}$, an index of the total productivity normalized to equivalent $\mathrm{C} 1$ products, are also reported. Tests at an applied voltage of -2.0 $\mathrm{V}$ vs $\mathrm{Ag} / \mathrm{AgCl}$. Average error on the values reported below $5 \%$.

\begin{tabular}{|c|c|c|c|c|c|c|c|c|}
\hline \multirow{2}{*}{\multicolumn{2}{|c|}{ Electrocatalysts }} & \multicolumn{7}{|c|}{$\begin{array}{l}\text { Normalized productivity with respect to current intensity }\left(\mu \mathrm{mol} \mathrm{h}^{-1} \cdot \mathrm{A}^{-1}\right) \text {; round brackets the normalized Turnover frequency - nTOF }{ }^{[1]}\left(\mathrm{h}^{-1} \cdot \mathrm{A}^{-1}\right) \text { with } \\
\text { respect to the molar concentration of surface metal atoms in NPs of the electrocatalysts }\end{array}$} \\
\hline & & $\begin{array}{l}\text { Formic } \\
\text { Acid }\end{array}$ & Acetic Acid & Methanol & Acetone & Iso-propanol & Ethanol & $\left.\mathrm{C}_{\mathrm{SUM}}\right]^{[2]}\left[\mathrm{C}_{1-}\right.$ \\
\hline \multirow{6}{*}{$\begin{array}{l}\text { INORG } \\
\text { Route }\end{array}$} & $\mathrm{CNT}_{\mathrm{ox}}$ & 4.67 & 1.79 & $<0.1^{[3]}$ & $<0.01^{[43]}$ & $<0.01^{[3]}$ & $<0.01^{[3]}$ & $6.46[13.4]$ \\
\hline & $\begin{array}{l}\mathrm{Pt}_{\text {INORG- }} \\
\text { CNT }\end{array}$ & $\begin{array}{l}22.91 \\
(0.301)\end{array}$ & $17.94(0.236)$ & $0.1^{[3]}\left(<0.0015^{[3]}\right)$ & $<0.01^{[3]}\left(<0.00015^{[3]}\right)$ & $<0.01^{[3]}\left(<0.00015^{[3]}\right)$ & $<0.01^{[3]}\left(<0.00015^{[4]}\right)$ & $\begin{array}{l}40.85[59.98] \\
(0.54[0.78])\end{array}$ \\
\hline & $\begin{array}{l}\text { Fe }_{\text {INORG- }} \\
\text { CNT }\end{array}$ & $\begin{array}{l}4.26 \\
(0.027)\end{array}$ & $5.41(0.034)$ & $1.84(0.012)$ & $0.06(0.0004)$ & $0.03(0.0002)$ & $<0.01^{[3]}\left(<0.00007^{[3]}\right)$ & $\begin{array}{l}11.60[17.24] \\
(0.07[0.11])\end{array}$ \\
\hline & $\begin{array}{l}\mathrm{Ru}_{\mathrm{INORG}^{-}} \\
\mathrm{CNT}\end{array}$ & $\begin{array}{l}34.85 \\
(0.085)\end{array}$ & $13.82(0.034)$ & $34.90(0.085)$ & $<0.01^{[3]}\left(<0.00005^{[3]}\right)$ & $<0.01^{[3]}\left(<0.00003^{[3]}\right)$ & $0.45(0.0011)$ & $\begin{array}{l}84.02[93.36] \\
(0.21[0.24])\end{array}$ \\
\hline & $\begin{array}{l}\mathrm{Ru}_{\text {INORG- }} \\
\text { CNT2\% }\end{array}$ & $\begin{array}{l}4.20 \\
(0.035)\end{array}$ & $2.90(0.024)$ & $1.30(0.011)$ & $<0.01^{[3]}\left(<0.00015^{[3]}\right)$ & $<0.01^{[3]}\left(<0.00009^{[3]}\right)$ & $0.20(0.0017)$ & $\begin{array}{l}8.60[11.77] \\
(0.07[0.09])\end{array}$ \\
\hline & $\begin{array}{l}\mathrm{Cu}_{\mathrm{INORG}^{-}} \\
\mathrm{CNT}\end{array}$ & $\begin{array}{l}19.79 \\
(0.660)\end{array}$ & $11.94(0.398)$ & $0.92(0.031)$ & $0.46(0.015)$ & $<0.01^{[4]}\left(<0.0004^{[4]}\right)$ & $1.40(0.047)$ & $\begin{array}{l}34.54[48.85] \\
(1.15[1.63])\end{array}$ \\
\hline \multirow{3}{*}{$\begin{array}{l}\text { OM } \\
\text { Route }\end{array}$} & $\mathrm{Pt}_{\mathrm{OM}}-\mathrm{CNT}$ & $\begin{array}{l}88.12 \\
(1.049)\end{array}$ & $5.25(0.0625)$ & $0.84(0.010)$ & $<0.01^{[3]}\left(<0.00015^{[3]}\right)$ & $0.03(0.0004)$ & $0.03(0.00036)$ & $\begin{array}{l}94.27 \text { [99.67] } \\
(1.12[1.19])\end{array}$ \\
\hline & $\mathrm{Fe}_{\mathrm{OM}^{-}} \mathrm{CNT}$ & $\begin{array}{l}15.97 \\
(0.055)\end{array}$ & $<\mathbf{1}^{[3]}\left(<0.003^{[3]}\right)$ & $10.10(0.035)$ & $0.26(0.0009)$ & $0.17(0.0006)$ & $<0.01^{[3]}\left(<0.00004^{[3]}\right)$ & $\begin{array}{l}26.50[29.55] \\
(0.09[0.10])\end{array}$ \\
\hline & $\mathrm{Ru}_{\mathrm{OM}}{ }^{-} \mathrm{CNT}$ & $\begin{array}{l}37.42 \\
(0.253)\end{array}$ & $13.45(0.091)$ & $129.08(0.872)$ & $0.22(0.0015)$ & $0.84(0.0057)$ & $0.78(0.0053)$ & $\begin{array}{l}181.79 \\
{[198.98](1.23} \\
[1.34])\end{array}$ \\
\hline NW & $\begin{array}{l}\mathrm{Cu}_{\mathrm{NW}^{-}} \\
\mathrm{CNT}^{[4]}\end{array}$ & $\begin{array}{l}65.06 \\
(0.834)\end{array}$ & $14.01(0.180)$ & $48.58(0.623)$ & $0.08(0.0010)$ & $0.08(0.0010)$ & $0.19(0.0024)$ & $\begin{array}{l}128[142.60] \\
(1.64[1.83])\end{array}$ \\
\hline
\end{tabular}

[1] TOF: calculated by dividing the productivity $\left(\mu \mathrm{mol} \mathrm{hr}{ }^{-1} \cdot \mathrm{A}^{-1}\right.$ ) by the $\mu \mathrm{mol}$ of metal on the surface of the nanoparticle ( $\mathrm{M}_{\text {surf, }}$ see Table 2 ).

${ }^{[2]} \mathrm{C}_{\mathrm{SUM}}=$ cumulative sum of productivities to products of $\mathrm{CO}_{2}$ reduction; $\mathrm{C}_{1 \text {-eq }}$ is the sum of productivities weighted to account for their carbon chain length (1 for methanol and formic acid, 2 for methanol and ethanol, 3 for isopropanol and acetone).

[3] Below the detection limit (value reported offers an upper limit).

[4] Preparation and characteristics described in ref. [58]; NW = NanoWire. 
Table 3 compares the normalized productivity for the two electrocatalysts series. As reference, productivity for the bare CNT and for a few additional Cu-based reference electrocatalysts $[52,65]$ is also reported. The productivity is expressed in $\mu \mathrm{mol} \mathrm{h} \mathrm{h}^{-1} \cdot \mathrm{A}^{-1}$, thus normalized to the current intensity (A), to obtain an intrinsic productivity not depending on changes in the amount of metal. The normalized productivity is given for the different detected products: formic acid, acetic acid methanol, acetone, isopropanol, and ethanol. In addition, the cumulative productivity $\left(\mathrm{C}_{\text {SUM }}\right)$, which is indicative of the total efficiency of products formation in the $\mathrm{CO}_{2}$ electrocatalytic reduction (with respect to $\mathrm{H}_{2}$ formation), is also reported in Table 3 together with a further index $\left(\mathrm{C}_{1-\mathrm{eq}}\right.$; indicated between square brackets in the last column of the Table). This corresponds to a weighted sum of products with respect to the number of carbon atoms involved to consider that longer chain molecules require more $\mathrm{CO}_{2}$ molecules to be converted. This $\mathrm{C}_{1 \text {-eq }}$ index is thus an indication of the total productivity normalized to equivalent $\mathrm{C}_{1}$ products.

Table 3 also reports the normalized turnover frequency (nTOF), i.e., the normalized productivity divided by the molar surface atoms $\left(M_{\text {surf }}\right.$. see Table 2) estimated for the metallic NPs in the electrocatalysts. This index thus represents a minimal nTOF value, which assumes that all exposed surface metal atoms are electrocatalytically active.

To analyze better the data reported in Table 3, they were also elaborated in a graphical form. Fig. 5a reports the normalized productivity and product distribution for the $\mathrm{M}-\mathrm{CNT}(\mathrm{M}=\mathrm{Pt}, \mathrm{Fe}, \mathrm{Ru})$ electrocatalyst series prepared by INORG and OM routes. The OM route reaches more than a two-fold increase of productivity in $\mathrm{CO}_{2}$ reduction. When

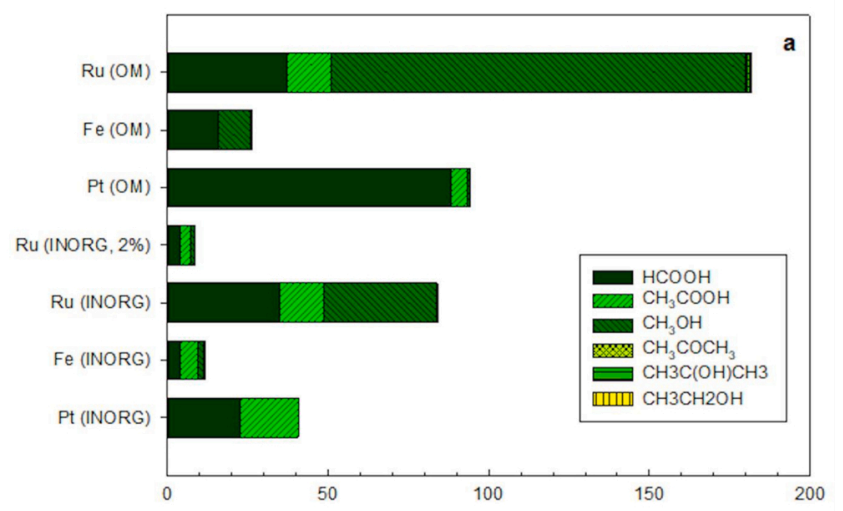

Normalized productivity with respect to current intensity $\left(\mu \mathrm{mol} \cdot \mathrm{h}^{-1} \cdot \mathrm{A}^{-1}\right)$

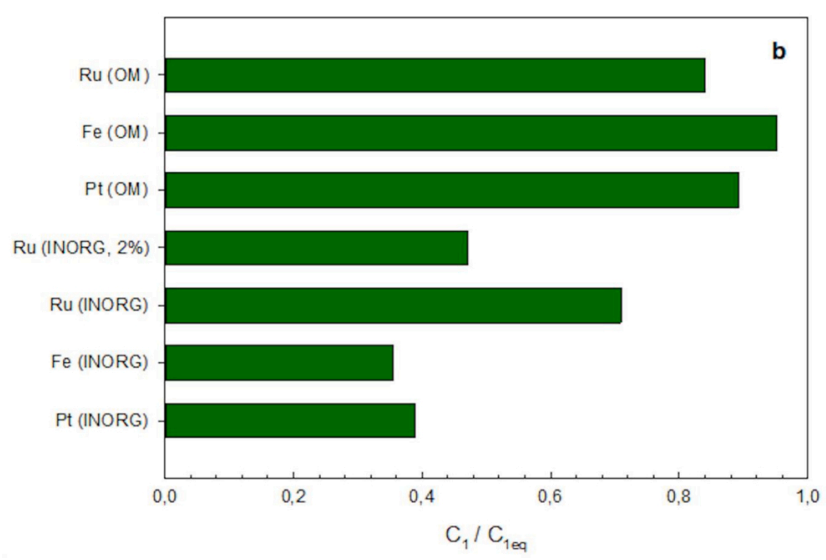

Fig. 5. (a) Cumulative productivities and product distribution in the $\mathrm{CO}_{2}$ electrocatalytic reduction over $\mathrm{M}-\mathrm{CNT}(\mathrm{M}=\mathrm{Pt}, \mathrm{Fe}, \mathrm{Ru})$ series prepared by INORG and OM routes. (b) Ratio between sum of the productivities to $\mathrm{C}_{1}$ products (formic acid and methanol) with respect to $\mathrm{C}_{1 \mathrm{eq}}$ (total productivity normalized to equivalent $\mathrm{C} 1$ products). Conditions as in Table 3. Average error on the values reported below $5 \%$. normalized to the current intensity, the data show an almost two-fold increase in $\mathrm{CO}_{2}$ reduction product formation, with respect to the sidereaction of $\mathrm{H}_{2}$ formation. There is, however, also a large difference in terms of products distribution, which depends on the metal. Formic acid and acetic acid are the two main products observed for $\mathrm{Pt}_{\text {INORG-CNT }}$ (with carbon weighted selectivity of about 39 and $61 \%$, respectively; see Fig. 6), $\mathrm{Pt}_{\mathrm{OM}}$-CNT also form mainly formic acid and acetic acid, but the relative selectivity to formic acid significantly increases reaching about $88 \%$. Note that these are values of selectivity relative to the carbon products formed.

For $\mathrm{Ru}_{\text {INORG }}$-CNT, methanol is also generated with a reasonable selectivity (about $36 \%$ ). The methanol selectivity largely increases when $\mathrm{Ru}_{\mathrm{OM}}-\mathrm{CNT}$ is used, reaching the highest value (65\%) obtained for all the investigated electrocatalysts. The normalized productivity of $\mathrm{Ru}_{\mathrm{INORG}}-\mathrm{CNT} 2 \%$, i.e., the sample prepared by INORG route with a metal loading and particle size more comparable to that of the electrocatalysts prepared by OM route, is instead the lowest obtained for all tested samples.

Fig. $5 \mathrm{~b}$ reports the relative formation of $\mathrm{C}_{1}$ products (formic acid and

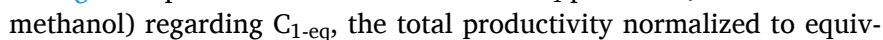
alent $C_{1}$ products. This index indicates the fraction of products with one carbon atom with respect to the total productivity to carbon-containing molecules (weighted to consider the different number of carbon atoms present in the products). While, on the average, the $\mathrm{C}_{1}$ path accounts for less than half of the $\mathrm{CO}_{2}$ conversion in the samples prepared by INORG route (except for $\mathrm{Ru}_{\mathrm{INORG}}-\mathrm{CNT}$, reaching about $70 \%$ ), the value is above $80 \%$ for all electrocatalysts prepared by OM routes, reaching about 95 $\%$ for $\mathrm{Fe}_{\mathrm{OM}^{-}}$-CNT. In this sample, $\mathrm{C}_{1}$ products (formic acid and methanol) are nearly exclusively observed as products of $\mathrm{CO}_{2}$ electrocatalytic reduction.

In comparison with bare CNT (Table 3), productivity of all M-CNT electrocatalysts is significantly higher, thus indicating that the electrocatalytic behavior is mainly associated to the metal NPs present on the CNTs. However, CNTs without metal exhibit some activity, yielding mainly formic acid along with acetic acid in lower amounts. This activity could derive from metal traces in the carbon nanotubes.

The reference copper based electrocatalysts (Table 3) show a behavior in line with those observed for the M-CNT ( $\mathrm{M}=\mathrm{Pt}, \mathrm{Fe}, \mathrm{Ru})$ series. Normalized productivity is 48.8 and 142.5 for $\mathrm{Cu}_{\text {INORG }}-\mathrm{CNT}$ and $\mathrm{Cu}_{\mathrm{NW}}$-CNT, respectively [58]. We add these samples here as reference for a better comparison and as support for the discussion. The preparation and characteristics of these samples were earlier reported by Marepally et al. [65]. The average size of the Cu NPs is $10.4 \mathrm{~nm}$ and 2.9 $\mathrm{nm}$ for $\mathrm{Cu}_{\text {INORG-CNT }}$ and $\mathrm{Cu}_{\mathrm{NW}}-\mathrm{CNT}$, respectively. The catalytic results of these reference samples confirm that smaller NPs (e.g. $\mathrm{Cu}_{\mathrm{NW}}-\mathrm{CNT}$ )

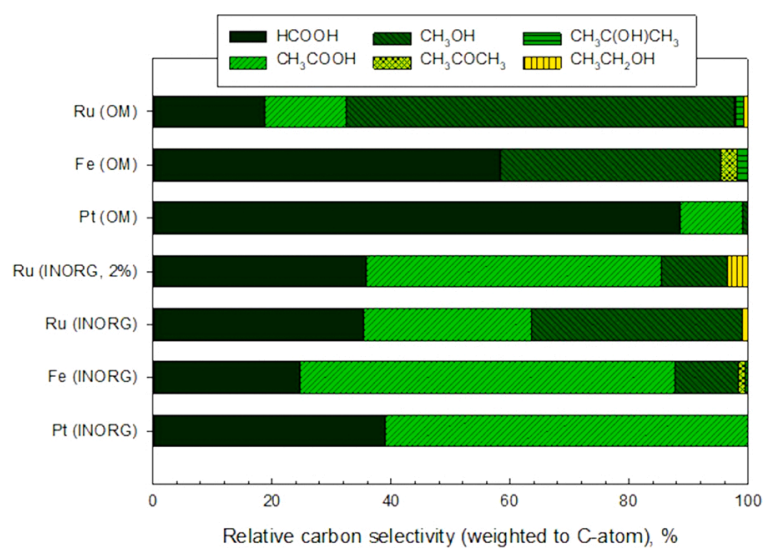

Fig. 6. Relative carbon selectivity (weighted to C-atoms) in the $\mathrm{CO}_{2}$ electrocatalytic reduction over M-CNT (M $=\mathrm{Pt}, \mathrm{Fe}, \mathrm{Ru})$ series prepared by INORG and OM routes. Conditions as in Table 3. Average error on the values reported below $5 \%$. 
allow to enhance the productivity and selectivity in $\mathrm{CO}_{2}$ reduction. Acetic and formic acids (49 and $41 \%$ selectivity on carbon basis, respectively; selectivity on carbon basis is defined as the product multiplied for the number of carbon atoms present in the product) are the main products for $\mathrm{Cu}_{\text {INORG }}$-CNT, but with about $6 \%$ selectivity to ethanol, the highest in the electrocatalyst series tested. $\mathrm{Cu}_{\mathrm{NW}}$-CNT shows instead a decreased selectivity to acetic acid (from about $49 \%$ to $20 \%$ ) and a corresponding increased selectivity to methanol (from $2 \%$ to $34 \%$; can see Supplementary Info). The scope here is not to discuss these copper-based electrocatalysts, that were earlier reported [65], but to evidence that the results obtained for the M-CNT $(M=P t, F e, R u)$ series is in line with those obtained using copper as the electroactive element. Further reasons for this comparison will be discussed later.

The behavior of M-CNT ( $\mathrm{M}=\mathrm{Pt}, \mathrm{Fe}, \mathrm{Ru})$ series in terms of normalized turnover frequency (nTOF), i.e., the normalized productivity divided by the molar surface atoms estimated for the metal NPs in the electrocatalysts, is reported in Fig. 7. $\mathrm{Ru}_{\mathrm{OM}}$-CNT shows the highest cumulative nTOF over the series of electrocatalysts tested which is over six times higher than for $\mathrm{Ru}_{\text {INORG }}$-CNT (1.23 vs 0.21 units, respectively) and one order of magnitude higher nTOF regarding $\mathrm{Ru}_{\text {INORG }}$-CNT $2 \%$ (1.23 vs 0.07 units, respectively) having a comparable metal loading as seen in Fig. 7. In addition, $\mathrm{Pt}_{\mathrm{OM}}-\mathrm{CNT}$ shows a significantly higher nTOF than that of the equivalent $\mathrm{Pt}_{\text {INORG-CNT, but only about two and half times }}$ higher (1.12 vs 0.54 units, respectively). The electrocatalysts based on iron show instead a low nTOF.

To further analyze these results, Fig. 8a reports the cumulative ratio of the normalized TOF in the various products of reaction during $\mathrm{CO}_{2}$ electrocatalytic reduction for the $\mathrm{M}_{\mathrm{OM}^{-}} \mathrm{CNT}(\mathrm{M}=\mathrm{Pt}, \mathrm{Fe}, \mathrm{Ru})$ series with respect to those of the $\mathrm{M}_{\mathrm{INORG}}-\mathrm{CNT}(\mathrm{M}=\mathrm{Pt}, \mathrm{Fe}, \mathrm{Ru})$ series. This figure evidences the boosting factor in TOF deriving from the OM route with respect to the INORG route.

While the effect is minor for Pt and Fe samples, a significant enhancement is observed for the Ru samples prepared by the OM route and the INORG route which exhibit a comparable Ru loading and particle size. In this specific case for Ru $2 \%$, when OM and INORG are compared, the cumulative improvement is over 90 times (Fig. 8a), with a remarkable selectivity increase for methanol by a factor of about 80 , considering that $\mathrm{Ru}_{\mathrm{OM}^{-}} \mathrm{CNT}$ is also the sample having the higher TOF (Fig. 7) and productivity (Fig. 5a). This result evidence that very specific and highly productive sites for methanol synthesis by $\mathrm{CO}_{2}$ electrocatalytic reduction are present in the $\mathrm{Ru}_{\mathrm{OM}^{-}} \mathrm{CNT}$ electrocatalyst.

To get more insight into the TOF per each product for all catalysts, the LOG of TOF ${ }_{\mathrm{OM}} / \mathrm{TOF}_{\text {INORG }}$ were plotted in Fig. 8b. Values above zero indicate that the TOF is higher for the $\mathrm{M}_{\mathrm{OM}}-\mathrm{CNT}(\mathrm{M}=\mathrm{Pt}, \mathrm{Fe}, \mathrm{Ru})$ series regarding the equivalent $\mathrm{M}_{\mathrm{INORG}}-\mathrm{CNT}(\mathrm{M}=\mathrm{Pt}, \mathrm{Fe}, \mathrm{Ru})$ series. The results

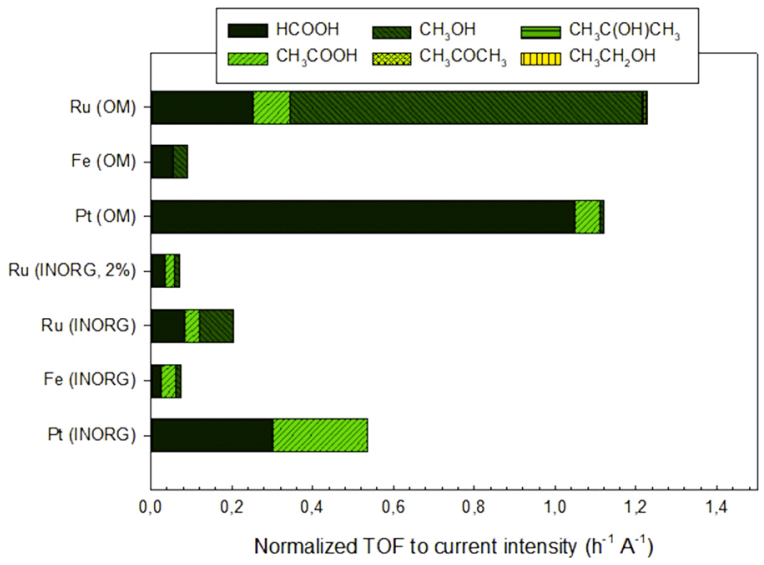

Fig. 7. Cumulative normalized TOF and product distribution in the $\mathrm{CO}_{2}$ electrocatalytic reduction over M-CNT (M $=\mathrm{Pt}, \mathrm{Fe}, \mathrm{Ru})$ series prepared by INORG and $\mathrm{OM}$ routes. Conditions as in Table 3. Average error on the values reported below $5 \%$.

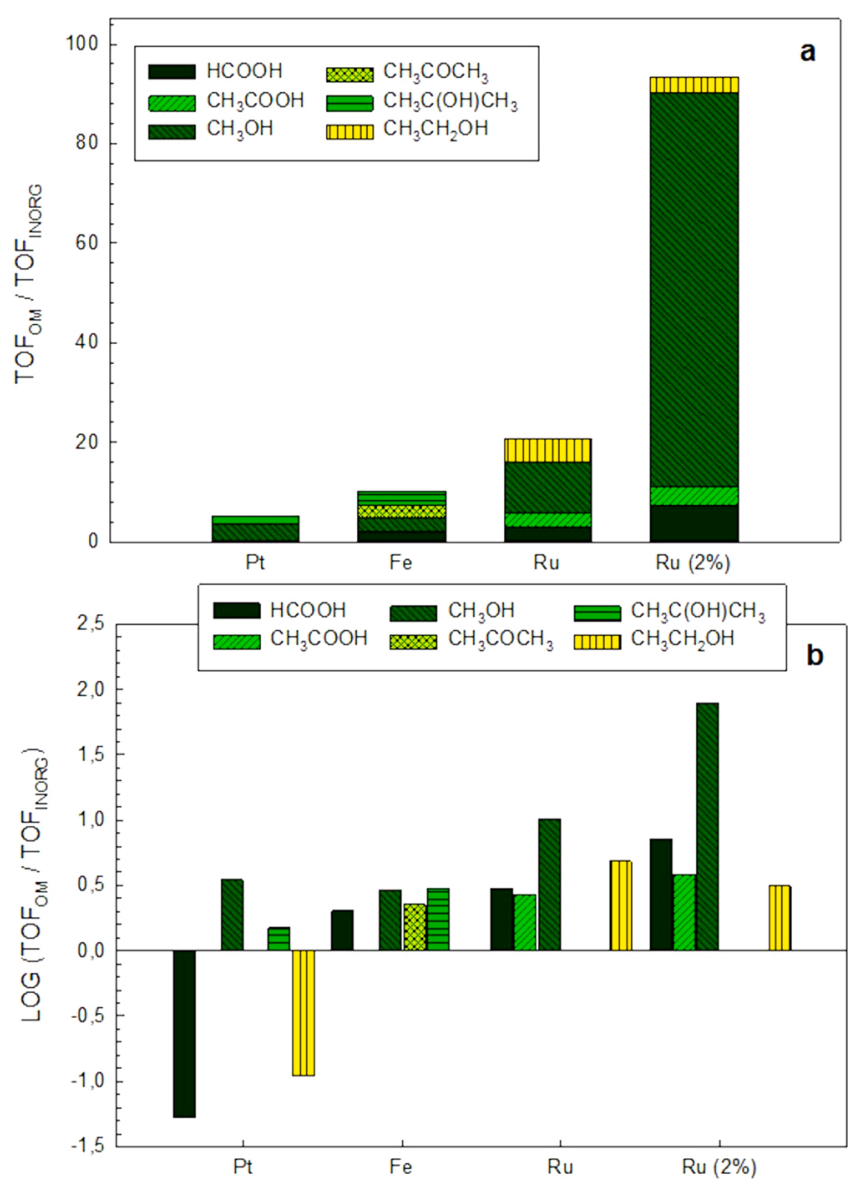

Fig. 8. (a) Cumulative ratio of the normalized TOF in the products of reaction during $\mathrm{CO}_{2}$ electrocatalytic reduction for $\mathrm{M}_{\mathrm{OM}}-\mathrm{CNT}(\mathrm{M}=\mathrm{Pt}, \mathrm{Fe}, \mathrm{Ru})$ series with respect to $\mathrm{M}_{\mathrm{INORG}}-\mathrm{CNT}\left(\mathrm{M}=\mathrm{Pt}, \mathrm{Fe}, \mathrm{Ru}\right.$ ) series. (b) LOG of $\mathrm{TOF}_{\mathrm{OM}} / \mathrm{TOF}_{\mathrm{INORG}}$ for the different products during $\mathrm{CO}_{2}$ electrocatalytic reduction for $\mathrm{M}_{\mathrm{OM}}-\mathrm{CNT}(\mathrm{M}=$ $\mathrm{Pt}, \mathrm{Fe}, \mathrm{Ru}$ ) series regarding $\mathrm{M}_{\mathrm{INORG}}-\mathrm{CNT}(\mathrm{M}=\mathrm{Pt}, \mathrm{Fe}, \mathrm{Ru})$ series Conditions as in Table 3. Average error on the values reported below $5 \%$.

show that positive values are mainly found (except for formic acid and ethanol with Pt samples) demonstrating that the ultrafine nanoparticles obtained via the OM route promote the formation of all products.

In the Supplementary Info, the Faradaic Efficiency (FE) to carbon products for the tested catalysts (Fig. S8a) and the LOG of $\mathrm{FE}_{\mathrm{OM}} / \mathrm{FE}_{\mathrm{INORG}}$ (Fig. S8b) are also reported. Ru catalysts (particularly with $2 \%$ metal loading) shows a positive LOG value, indicating that the OM route promotes FE to carbon containing products, while both Fe and Pt series give negative LOG values, and thus a lowering in the FE to carbon products.

The characterization of the spent electrocatalysts after $\mathrm{CO}_{2}$ reduction, by different methods including XPS, does not evidence significant changes well in agreement with the indication of a stable electrocatalytic behavior for at least $20 \mathrm{~h}$ of continuous tests. To illustrate this, a representative TEM micrograph of one of the spent catalysts (namely $\mathrm{Ru}_{\mathrm{INORG}}-\mathrm{CNT} 2 \%$ ) is provided in Fig. S9 (Supplementary Info). Mean NP size after the catalytic tests remained centered on $1.46 \mathrm{~nm}$, with a relatively narrow size distribution of $0.9-2 \mathrm{~nm}$ as in Fig. S9.

\section{Discussion}

The organometallic $(\mathrm{OM})$ route to prepare metal nanoparticles (NPs) supported over carbon nanotubes (CNTs) as electrocatalysts for the reduction of $\mathrm{CO}_{2}$ leads to catalysts exhibiting significantly different physical features and catalytic performances regarding those obtained with a more classical method based on metallic salts impregnation 
(INORG route). Although, metal loading yielded from the OM route is nearly one fifth of that obtained by the INORG route, the catalysts result more productive (Fig. 5a). They are more active with higher TOF with respect to surface metal atoms (Fig. 7), thus evidencing that the enhanced performances are not only related to the slightly smaller NPs sizes obtained by the OM route (Figs. 2 and 3, Table 1) but to an intrinsic change of the reactivity. This indication is further supported by the comparison between $\mathrm{Ru}_{\mathrm{OM}^{-}} \mathrm{CNT}$ and $\mathrm{Ru}_{\mathrm{INORG}}-\mathrm{CNT} 2 \%$ which are prepared using the two routes and a comparable metal loading. It is also worth noting that the catalysts exhibit different products selectivity, as evidenced in Fig. 6. One can note a general increase of the TOF, up to a 90-fold increase with $\mathrm{Ru}_{\mathrm{OM}}$-CNT in comparison with $\mathrm{Ru}_{\mathrm{INORG}}$-CNT2\% (Fig. 8a). Except for the formation of formic acid and ethanol on Pt samples, the enhancement of TOF is present for all products whatever the type of metal (Fig. 8b), although this enhancement depends on the type of products with methanol being the most influenced one. From the application perspective, carbon selectivity to methanol for $\mathrm{Ru}_{\mathrm{OM}}{ }^{-} \mathrm{CNT}$ reaches the interesting value of $65 \%$ and the catalysts were found stable under the reaction conditions explored. Faradaic Efficiency (FE) to carbon products is also enhanced in Ru samples prepared by the OM route, while for Fe and Pt samples FE is lower for samples prepared by the OM route. (Fig. S8b, Supplementary Info). Note that at least on the lab time scale, up to $20 \mathrm{~h}$ of continuous tests, these electrocatalysts result stable and give well reproducible results.

Thus an intrinsic effect of boosting the electrocatalytic performances on M-CNT electrocatalysts for $\mathrm{CO}_{2}$ reduction is observed. The analysis of TOF reveals that this is not only related to the smaller size of the metallic NPs obtained via the OM route. This is confirmed by the comparison

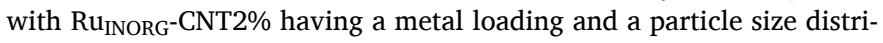
bution closer to that of $\mathrm{Ru}_{\mathrm{OM}^{-}} \mathrm{CNT}$ which shows on the contrary low productivity, TOF and Faradaic efficiency. These results indicate that the $\mathrm{OM}$ route allows to prepare catalysts with specific surface sites exhibiting enhanced activity whatever the nature of the metallic NPs introduced on the CNTs.

To analyse the alternative possible interpretations of this effect, may be started that during the preparation of catalysts using inorganic metal salts (INORG route), the counter ions of the metals in the precursor inorganic salt could be not completely removed and could influence the surface reactivity of the metal NPs. In our case, metal nitrate and chloride salts $\left(\mathrm{Fe}\left(\mathrm{NO}_{3}\right)_{3} \cdot 9 \mathrm{H}_{2} \mathrm{O}, \mathrm{RuCl}_{3} \cdot \mathrm{xH}_{2} \mathrm{O}\right.$ or $\left.\mathrm{H}_{2} \mathrm{PtCl}_{6} \cdot 6 \mathrm{H}_{2} \mathrm{O}\right)$ were used. A nitrate salt was also used for the copper samples used as references. When using chloride as anion, it is possible that $\mathrm{Cl}^{-}$anions remain adsorbed on the surface of the metal NPs but this is unlikely for nitrate anions. In addition, the effect observed is independent on the anions. In addition, XPS and EDX analyses do not provide evidence of the presence of residual $\mathrm{Cl}^{-}$ions in the catalyst. Therefore, the difference in the reactivity between the catalysts prepared by the OM and INORG routes could not reasonably related to poisoning by anions of the metal NPs. Note also that XPS do provide indications of differences in terms of metal surface oxidation state in NPs prepared by OM and INOR routes, and thus may be also excluded that difference in the metal surface species may impact electro-reduction performance and thus electrocatalytic behavior.

Another possible explanation could be a morphological change in the metal NPs (e.g. a change in the shape of the NPs) when using the two preparation routes (OM and INORG). One of the reference $\mathrm{Cu}$ samples, as earlier described [65], has a nanowire (NW) morphology rather than a round-shaped morphology as the samples prepared here by $\mathrm{OM}$ and INORG routes, as see TEM images in the Supplementary Info. This $\mathrm{Cu}_{\mathrm{NW}}$-CNT sample exhibits an higher productivity (Table 3) and a different products selectivity (with higher selectivity to methanol) in comparison to catalyst prepared by INORG route $\left(\mathrm{Cu}_{\mathrm{INORG}}-\mathrm{CNT}\right)$. However, in the M-CNT ( $\mathrm{M}=\mathrm{Pt}$, Fe, Ru) series, electron microscopy analysis does not reveal morphological changes in the metal NPs nor this could be observed by other characterization data, including XRD. Thus, no data indicate morphological changes as observed in the case of copper NW where this change in the nanomorphology is present [65]. We also do not observe changes in the exposed crystallographic planes of the metallic NPs in the M-CNT ( $\mathrm{M}=\mathrm{Pt}, \mathrm{Fe}, \mathrm{Ru})$ series.

The NPs formed via the OM route deposited on to the CNTs thus result more productive and favour the path of reduction of $\mathrm{CO}_{2}$ over the competitive reaction of electrons with $\mathrm{H}^{+}$to generate $\mathrm{H}_{2}$, but this change in the reactivity with respect to samples prepared by a more conventional route (INORG) cannot be interpreted in terms of size of the metal nanoparticles, changes in their shape or in the metal oxidation state. There is thus an additional effect. Note also that a change in the product distribution is noted, which cannot be associated to the above effects, i.e., those commonly considered in analysing the electrocatalytic data. The results also remark the considerable dependence of the boosting effect on the type of metal used, leading to electrocatalytic results of relevance for a metal such as Ru which is not among those typically studied in the electrocatalytic reduction of $\mathrm{CO}_{2}$, notwithstanding some recent results discussed in the introduction. We believe that this boosting effect is related to the presence of small oxidic patches on the metal NPs formed as residues during the process of removal of the ligands (OM route). This interpretation, however, deserve further studies.

$\mathrm{Ru}_{\mathrm{OM}}$-CNT shows a large (up to two order of magnitude) increase in TOF regarding $\mathrm{Ru}_{\mathrm{INORG}}-\mathrm{CNT} 2 \%$ having comparable $\mathrm{Ru}$ loading and particle size. In addition, $\mathrm{C}_{1}$ products were largely promoted. In $\mathrm{Ru}_{\mathrm{OM}^{-}}$ CNT there is an increasing factor in TOF of methanol of over 10 with respect to that obtained using $\mathrm{Ru}_{\mathrm{INORG}}-\mathrm{CNT}$ and up to nearly 80 regarding that of $\mathrm{Ru}_{\text {INORG }}-\mathrm{CNT} 2 \%$. Fig. $5 \mathrm{~b}$ also evidences that the $\mathrm{C}_{1}$ path drastically increases for electrocatalysts prepared by the OM route with respect to those prepared by the INORG route.

$\mathrm{Ru}$ gives better results with respect to those provided by $\mathrm{Pt}$ and especially by Fe. While a specificity of the metal itself is observed, we determined by XPS the full reduction of Ru NPs while, for Pt, some $\mathrm{Pt}^{\mathrm{IV}}$ was detected and the presence of iron-oxide on the iron NPs (Fig. S4, Supplementary Info). This indicates that the re-oxidation tendency decreases in the following order: $\mathrm{Ru}>\mathrm{Pt}>>\mathrm{Fe}$, which is well in line with the productivity order in both catalyst series obtained by the $\mathrm{OM}$ and INORG routes (Fig. 5a). This result is well in line with the fact that oxidized sites on metal nanoparticles could affect the electron accumulation on the metal NPs during the electrocatalytic reaction and thus the rate of electron transfer and productivity.

\section{Conclusions}

The results presented here demonstrate that metal NPs prepared by OM route and deposited on CNTs in comparison to NPs prepared via INORG route exhibit a largely enhanced productivity and especially better selectivity to methanol particularly by using $\mathrm{Ru}$ as metal. Although the preparation by OM route could be more costly than the traditional one, the main point here is not to propose novel preparation routes (even if OM method has been scarcely used to prepare electrocatalysts), but to demonstrate that the control of the surface characteristics of metal NPs could lead to drastic, up to about two order of magnitude increase in the TOF, with also an interesting increase in the selectivity (up to $65 \%$ in methanol) and control of the paths of $\mathrm{CO}_{2}$ transformation.

Although further studies are necessary to clarify this point, we propose here that this large boosting effect, both in TOF and selectivity, is related to the presence of small surface oxidic patches on the metal NPS related to residues in the process of removal of ligands used in OM preparation. Other methods reproducing these characteristics could be used to prepare the electrocatalysts, but we feel that this is the first time that this boosting effect in the electrocatalytic reduction of $\mathrm{CO}_{2}$ was shown particularly for a metal such as Ru still less investigated for this reaction. In addition, to our knowledge this is also the first time that this boosting effect in proposed to be associated to the presence of small oxidic patches over the metal NPs. Thus, we feel that the results 
presented here could contribute to open new directions of research in the area and establish new preparation routes for $\mathrm{CO}_{2}$ electrocatalysts.

\section{Author's contributions}

Dr. B. C. Marepally - major work in design, synthesis and testing. Prof. C. Ampelli - design and development of catalytic cell and project guidance. Prof. G. Centi, manuscript writing and revision. Prof.s S. Perathoner, E. A. Quadrelli, Dr. C. Thieuleux manuscript corrections, knowledge addition and project guidance. Dr. C. Genovese, Dr. R. Sayah, L. Veyre, C. Dalverny - aid in the analysis of the catalysts.

\section{Declaration of Competing Interest}

I declare that there are no conflicts of interest in presenting this manuscript for publication on the Journal of $\mathrm{CO}_{2}$ Utilization.

\section{Acknowledgements}

The authors thank the European Joint Doctoral Programme on Sustainable Industrial Chemistry (SINCHEM - Erasmus + Action 1 Programme (FPA 2013-0037)) for supporting M. Bhanu Chandra's PhD at the University of Messina in co-tutelle with C2P2 laboratory (UMR 5265), whose three tutelles CNRS, UCBL, and CPE Lyon are also kindly acknowledged. Dr. M. Bhanu Chandra also thanks the DST-SERB, India for supporting the research on $\mathrm{CO}_{2}$ reduction under Core Research Grant (CRG/2019/005985). UniME researchers would thank the MIUR PRIN2017 project support ( $\mathrm{CO}_{2}$ ONLY, grant number 2017WR2LRS) and the European Research Council (ERC) under the European Union's Horizon 2020 research and innovation programme (ERC Synergy project SCOPE, grant agreement No 810182).

\section{Appendix A. Supplementary data}

Supplementary material related to this article can be found, in the online version, at doi:https://doi.org/10.1016/j.jcou.2021.101613.

\section{References}

[1] S. Liang, N. Altaf, L. Huang, Y. Gao, Q. Wang, Electrolytic cell design for electrochemical $\mathrm{CO}_{2}$ reduction, J. $\mathrm{CO}_{2}$ Utiliz. 35 (2020) 90-105.

[2] Qi. Lia, X. Rao, J. Sheng, J. Xu, J. Yi, Y. Liu, J. Zhang, Energy storage through $\mathrm{CO}_{2}$ electroreduction: a brief review of advanced Sn-based electrocatalysts and electrodes, J. CO2 Utiliz. 27 (2018) 48-59.

[3] D. Yang, B. Ni, X. Wang, Heterogeneous catalysts with well-defined active metal sites toward $\mathrm{CO}_{2}$ electrocatalytic reduction, Adv. Energy Mater. 10 (2020), 2001142.

[4] Y. Zhang, S.-X. Guo, X. Zhang, A.M. Bond, J. Zhang, Mechanistic understanding of the electrocatalytic $\mathrm{CO}_{2}$ reduction reaction - new developments based on advanced instrumental techniques, Nano Today 31 (2020), 100835.

[5] A. Liu, M. Gao, X. Ren, F. Meng, Y. Yang, L. Gao, Q. Yang, T. Ma, Current progress in electrocatalytic carbon dioxide reduction to fuels on heterogeneous catalysts, J. Mater. Chem. A 8 (2020) 3541-3562.

[6] S. Zhang, Q. Fan, R. Xia, T.J. Meyer, $\mathrm{CO}_{2}$ reduction: from homogeneous to heterogeneous electrocatalysis, Acc. Chem. Res. 53 (2020) 255-264.

[7] L. Sun, V. Reddu, A.C. Fisher, X. Wang, Electrocatalytic reduction of carbon dioxide: opportunities with heterogeneous molecular catalysts, Energy \& Env. Science 13 (2020) 374-403.

[8] F. Lu, H. Bao, Y. Mi, Y. Liu, J. Sun, X. Peng, Y. Qiu, L. Zhuo, X. Liu, J. Luo, Electrochemical $\mathrm{CO}_{2}$ reduction: from nanoclusters to single atom catalysts, Sustain. Energy Fuels 4 (2020) 1012-1028.

[9] D. Salvatore, C.P. Berlinguette, Voltage matters when reducing $\mathrm{CO}_{2}$ in an electrochemical flow cell, ACS Energy Lett. 5 (2020) 215-220.

[10] J.O. Taylor, Y. Wang, F. Hartl, Photo-assisted electrocatalytic reduction of $\mathrm{CO}_{2}$ : a new strategy for reducing catalytic overpotentials, ChemCatChem 12 (2020) 386-393.

[11] A. Sacco, J. Zeng, K. Bejtka, A. Chiodoni, Modeling of gas bubble-induced mass transport in the electrochemical reduction of carbon dioxide on nanostructured electrodes, J. Catal. 372 (2019) 39-48.

[12] Y. Zhang, L. Li, S.-X. Guo, X. Zhang, F. Li, A.M. Bond, J. Zhang, Two-dimensional electrocatalysts for efficient reduction of carbon dioxide, ChemSusChem 13 (2020) 59-77.

[13] H. Rabiee, L. Ge, X. Zhang, S. Hu, M. Li, Z. Yuan, Gas diffusion electrodes (GDEs) for electrochemical reduction of carbon dioxide, carbon monoxide, and dinitrogen to value-added products: a review, Energy Environ. Sci. 14 (2021) 1959-2008, https://doi.org/10.1039/D0EE03756G.

[14] G. Wang, J. Chen, Y. Ding, P. Cai, L. Yi, Y. Li, C. Tu, Y. Hou, Z. Wen, L. Dai, Electrocatalysis for $\mathrm{CO}_{2}$ conversion: from fundamentals to value-added products, Chem. Soc. Rev. 50 (2021) 4993-5061, https://doi.org/10.1039/D0CS00071J.

[15] S. Perathoner, G. Centi, Catalysis for solar-driven chemistry: the role of electrocatalysis, Catal. Today 330 (2019) 157-170.

[16] G. Centi, S. Perathoner, Chemistry and energy beyond fossil fuels. A perspective view on the role of syngas from waste sources, Catal. Today 342 (2020) 4-12.

[17] X. Li, J. Yu, M. Jaroniec, X. Chen, Cocatalysts for selective photoreduction of $\mathrm{CO}_{2}$ into solar fuels, Chem. Rev. 119 (2019) 3962-4179.

[18] N. Roy, N. Suzuki, C. Terashima, A. Fujishima, Recent improvements in the production of solar fuels: from $\mathrm{CO}_{2}$ reduction to water splitting and artificial photosynthesis, Bull. Chem. Soc. Jpn. 92 (2019) 178-192.

[19] S. Hennessey, P. Farras, Production of solar chemicals: gaining selectivity with hybrid molecule/semiconductor assemblies, Chem. Comm. 54 (2018) 6662-6680.

[20] G. Chen, R. Shi, J. Zhao, Z. Li, L.-Z. Wu, C.-H. Tung, T. Zhang, G. Chen, G.I. N. Waterhouse, T. Zhang, From solar energy to fuels: recent advances in lightdriven C1 chemistry, Angew, Chem. Int. Ed. 58 (2019) 17528-17551.

[21] P. Lanzafame, S. Abate, C. Ampelli, C. Genovese, R. Passalacqua, G. Centi, S. Perathoner, Beyond solar fuels: renewable energy-driven chemistry, ChemSusChem 10 (2017) 4409-4419.

[22] G. Centi, E.A. Quadrelli, S. Perathoner, Catalysis for $\mathrm{CO}_{2}$ conversion: a key technology for rapid introduction of renewable energy in the value chain of chemical industries, Energy \& Env. Science 6 (2013) 1711-1731.

[23] S. Liu, S. Huang, Structure engineering of Cu-based nanoparticles for electrochemical reduction of $\mathrm{CO}_{2}$, J. Catal. 375 (2019) 234-241.

[24] I.A. Morena-Hernandez, S. Yalamanchili, H.J. Fu, H.A. Atwater, B.S. Brunschwig, N.S. Lewis, Conformal $\mathrm{SnO}_{\mathrm{x}}$ heterojunction coatings for stabilized photoelectrochemical water oxidation using arrays of silicon microcones, J. Mater. Chem. A 8 (2020) 9292-9301.

[25] B.C. Marepally, C. Ampelli, C. Genovese, F. Tavella, E.A. Quadrelli, S. Perathoner, G. Centi, Electrocatalytic reduction of $\mathrm{CO}_{2}$ over dendritic-type $\mathrm{Cu}$-and $\mathrm{Fe}-$ based electrodes prepared by electrodeposition, J. CO 2 Util. 35 (2020) 195-204.

[26] S. Nitopi, E. Bertheussen, S.B. Scott, X. Liu, A.K. Engstfeld, S. Horch, B. Seger, I.E. L. Stephens, K. Chan, C. Hahn, J.K. Norskov, T.F. Jaramillo, Ib Chorkendorff, Progress and perspectives of electrochemical $\mathrm{CO}_{2}$ reduction on copper in aqueous electrolyte, Chem. Rev. 119 (2019) 7610-7672.

[27] B.C. Marepally, C. Ampelli, C. Genovese, E.A. Quadrelli, S. Perathoner, G. Centi, Production of solar fuels using $\mathrm{CO}_{2}$ - horizons in sustainable industrial chemistry and catalysis, Studies Surf. Sci. Catal., Elsevier 178 (2019) 7-30.

[28] A.A. Peterson, J.K. Norskov, Activity descriptors for $\mathrm{CO}_{2}$ electroreduction to methane on transition-metal catalysts, J. Phys. Chem. Lett. 3 (2012) 251-258.

[29] J. Hussain, E. Skúlason, H. Jónsson, Computational study of electrochemical $\mathrm{CO}_{2}$ reduction at transition metal electrodes, Procedia Comput. Sci. 51 (2015) 1865-1871.

[30] D. Gao, H. Zhou, J. Wang, S. Miao, F. Yang, G. Wang, J. Wang, X. Bao, Sizedependent electrocatalytic reduction of $\mathrm{CO}_{2}$ over Pd nanoparticles, J. Am. Chem. Soc. 137 (2015) 4288-4291.

[31] C. Ampelli, C. Genovese, B.C. Marepally, G. Papanikolaou, S. Perathoner, G. Centi, Electrocatalytic conversion of $\mathrm{CO}_{2}$ to produce solar fuels in electrolyte or electrolyte-less configurations of PEC cells, Faraday Discuss. 183 (2015) 125-145.

[32] R. Reske, H. Mistry, F. Behafarid, B.R. Cuenya, P. Strasser, Particle size effects in the catalytic electroreduction of $\mathrm{CO}_{2}$ on $\mathrm{Cu}$ nanoparticles, J. Am. Chem. Soc. 136 (2014) 6978-6986.

[33] K.S. Bhavani, T. Anusha, P.K. Brahman, Fabrication and characterization of gold nanoparticles and fullerene-C60 nanocomposite film at glassy carbon electrode as potential electro-catalyst towards the methanol oxidation, Int. J. Hydrog. Energy 44 (2019) 25863-25873.

[34] H. Mistry, R. Reske, Z. Zeng, Z.J. Zhao, J. Greeley, P. Strasser, B.R. Cuenya, Exceptional size-dependent activity enhancement in the electroreduction of $\mathrm{CO}_{2}$ over Au nanoparticles, J. Am. Chem. Soc. 136 (2014) 16473-16476.

[35] S.S. Kumar, S.U.B. Ramakrishna, K.N. Mahesh, B.R. Devi, V. Himabindu, Palladium supported on phosphorus-nitrogen dual-doped carbon nanoparticles as cathode for hydrogen evolution in PEM water electrolyser, Ionics 25 (2019) 2615-2625.

[36] Y. Huang, A.D. Handoko, P. Hirunsit, B.S. Yeo, Electrochemical reduction of $\mathrm{CO}_{2}$ using copper single-crystal surfaces: effects of $\mathrm{CO} *$ coverage on the selective formation of ethylene, ACS Catal. 7 (2017) 1749-1756.

[37] M. Chandrika, A.V. Ravindra, Ch. Rajesh, S.D. Ramarao, S. Ju, Studies on structural and optical properties of nano $\mathrm{ZnFe}_{2} \mathrm{O}_{4}$ and $\mathrm{ZnFe}_{2} \mathrm{O}_{4}-\mathrm{TiO}_{2}$ composite synthesized by co-precipitation route, Mater. Chem. Phys. 230 (2019) 107-113.

[38] K.J.P. Schouten, Z. Qin, E.P. Gallent, M.T.M. Koper, Two pathways for the formation of ethylene in CO reduction on single-crystal copper electrodes, JACS 134 (2012) 9864-9867.

[39] J.H. Montoya, C. Shi, K. Chan, J.K. Noerskov, Theoretical insights into a CO dimerization mechanism in $\mathrm{CO}_{2}$ electroreduction, J. Phys. Chem. Lett. 6 (2015) 2032-2037.

[40] J.D. Goodpaster, A.T. Bell, M. Head-Gordon, Identification of possible pathways for $\mathrm{C}-\mathrm{C}$ bond formation during electrochemical reduction of $\mathrm{CO}_{2}$ : new theoretical insights from an improved electrochemical model, J. Phys. Chem. Lett. 7 (2016) 1471-1477.

[41] B.C. Marepally, C. Ampelli, C. Genovese, T. Saboo, S. Perathoner, F.M. Wisser, L. Veyre, J. Canivet, E.A. Quadrelli, G. Centi, Enhanced formation of \&C 1 products in the electroreduction of $\mathrm{CO}_{2}$ by adding a carbon dioxide adsorption component to a gas diffusion layer type catalytic electrode, ChemSusChem 10 (2017) 4442-4446. 
[42] Y.Y. Birdja, E. Pérez-Gallent, M.C. Figueiredo, A.J. Göttle, F. Calle-Vallejo, M.T. M. Koper, Advances and challenges in understanding the electrocatalytic conversion of carbon dioxide to fuels, Nat. Energy 4 (2019) 732-745.

[43] Y. Li, D. Kim, S. Louisia, C. Xie, Q. Kong, S. Yu, T. Lin, S. Aloni, S.C. Fakra, P. Yang, Electrochemically scrambled nanocrystals are catalytically active for $\mathrm{CO}_{2}$-tomulticarbons, PNAS 117 (2020) 9194-9201.

[44] Y.-T. Chan, I.-S. Huang, M.-K. Tsai, Enhancing C-C bond formation by surface strain: a computational investigation for $\mathrm{C} 2$ and C3 intermediate formation on strained Cu surfaces, Phys. Chem. Chem. Phys. 21 (2019) 22704-22710.

[45] Y. Lum, B.Yue P. Lobaccaro, A.T. Bell, J.W. Ager, Optimizing C-C coupling on oxide-derived copper catalysts for electrochemical $\mathrm{CO}_{2}$ reduction, J. Phys. Chem. C 121 (2017) 14191-14203.

[46] C. Genovese, C. Ampelli, S. Perathoner, G. Centi, Mechanism of C-C bond formation in the electrocatalytic reduction of $\mathrm{CO}_{2}$ to acetic acid. A challenging reaction to use renewable energy with chemistry, Green Chem. 19 (2017) 2406-2415.

[47] X. Chang, A. Malkani, X. Yang, B. Xu, Mechanistic insights into electroreductive C-C coupling between $\mathrm{CO}$ and acetaldehyde into multicarbon products, J. Am. Chem. Soc. 142 (2020) 2975-2983.

[48] T.-T. Zhuang, Y. Pang, Z.-Q. Liang, Z. Wang, Y. Li, C.-S. Tan, J. Li, C.T. Dinh, P. De Luna, P.-L. Hsieh, et al., Copper nanocavities confine intermediates for efficient electrosynthesis of C3 alcohol fuels from carbon monoxide, Nature Catal. 1 (2018) 946-951.

[49] B.-B. Zhang, Y.-H. Wang, S.-M. Xu, K. Chen, Y.-G. Yang, Q.-H. Kong, Tuning nanocavities of $\mathrm{Au} @ \mathrm{Cu}_{2} \mathrm{O}$ yolk-shell nanoparticles for highly selective electroreduction of $\mathrm{CO}_{2}$ to ethanol at low potential, RSC Adv. 10 (2020) 19192-19198.

[50] S. Sen, D. Liu, G.T.R. Palmore, Electrochemical reduction of $\mathrm{CO}_{2}$ at copper nanofoams, ACS Catal. 4 (2014) 3091-3095.

[51] S. Yu, A.J. Wilson, J. Heo, P.K. Jain, Plasmonic control of multi-electron transfer and $\mathrm{C}-\mathrm{C}$ coupling in visible-light-Driven $\mathrm{CO}_{2}$ reduction on Au nanoparticles, Nano Lett. 18 (2018) 2189-2194.

[52] K. Pelzer, B. Laleu, F. Lefebvre, K. Philippot, B. Chaudret, J.P. Candy, J.M. Basset, New Ru nanoparticles stabilized by organosilane fragments, Chem. Mater. 16 (2004) 4937-4941.

[53] P. Laurent, L. Veyre, C. Thieuleux, S. Donet, C. Copéret, From well-defined Pt(II) surface species to the controlled growth of silica supported Pt nanoparticles, Dalton Trans. 42 (2013) 238-248.
[54] T. Andana, M. Piumetti, S. Bensaid, L. Veyre, C. Thieuleux, N. Russo, D. Fino, Elsje A. Quadrelli, R. Pirone, Ceria-supported small Pt and $\mathrm{Pt}_{3} \mathrm{Sn}$ nanoparticles for NOxassisted soot oxidation, Appl. Catal. B 209 (2017) 295-310.

[55] N. Sadri, S.J. Hoseini, Oxidative addition of 1,4-dichloro-2-butyne to an organoplatinum complex: a new precursor for synthesis of ultrasmall Pt nanoparticles thin film at liquid/liquid interface as the electrocatalyst in methanol oxidation reaction, Appl. Organometal. Chem. 33 (2019) e5018.

[56] A. Barbanente, N. Margiotta, C. Pacifico, F.P. Intini, G. Natile, One-pot synthesis of new organometallic compounds with platinum-carbon bond, Organometal. Chem. 2020 (2019) 1018-1026.

[57] A. Barbanente, N. Margiotta, C. Pacifico, F.P. Intini, G. Natile, One-pot synthesis of new organometallic compounds with platinum-carbon bond, Organometal. Chem. 11-12 (2020) 1018-1026.

[58] L.M.M. Prieto, B. Chaudret, Organometallic ruthenium nanoparticles: synthesis, surface chemistry, and insights into ligand coordination, Acc. Chem. Res. 51 (2018) 376-384.

[59] M. Boualleg, S. Norsic, D. Baudouin, R. Sayah, E.A. Quadrelli, J.-M. Basset, J.P. Candy, P. Delichere, K. Pelzer, L. Veyre, C. Thieuleux, Selective and regular localization of accessible Pt nanoparticles inside the walls of an ordered silica: application as a highly active and well-defined heterogeneous catalyst for propene and styrene hydrogenation reactions, J. Catal. 284 (2011) 184-193.

[60] C. Genovese, C. Ampelli, S. Perathoner, G. Centi, Electrocatalytic conversion of $\mathrm{CO}_{2}$ to liquid fuels using nanocarbon-based electrodes, J. Energy Chem. 22 (2013) 202-213.

[61] E. Tayyebi, J. Hussain, E. Skulason, Why do $\mathrm{RuO}_{2}$ electrodes catalyze electrochemical $\mathrm{CO}_{2}$ reduction to methanol rather than methane or perhaps neither of those? Chem. Science 11 (2020) 9542-9553.

[62] T.-T. Li, B. Shan, W. Xu, T.J. Meyer, Electrocatalytic $\mathrm{CO}_{2}$ reduction with a ruthenium catalyst in solution and on nanocrystalline $\mathrm{TiO}_{2}$, ChemSusChem 12 (2019) 2402-2408.

[63] W.D. Pyrz, D.J. Buttrey, Particle size determination using TEM: a discussion of image acquisition and analysis for the novice microscopist, Langmuir 24 (2008) 11350-11360.

[64] C.A. Schneider, W.S. Rasband, K.W. Eliceiri, NIH Image to ImageJ: 25 years of image analysis, Nat. Methods 9 (2012) 671-675.

[65] B.C. Marepally, C. Ampelli, C. Genovese, F. Tavella, L. Veyre, E.A. Quadrelli, S. Perathoner, G. Centi, Ultrafine Cu nanoparticles onto nanocarbon-based electrodes for the electrocatalytic reduction of $\mathrm{CO}_{2}, \mathrm{~J} . \mathrm{CO}_{2}$ Util. 21 (2017) 534-542. 